\title{
Recent Insights into the Measurement of Carbon Dioxide Concentrations for Clinical Practice in Respiratory Medicine
}

\author{
Akira Umeda ${ }^{1, *}$, Masahiro Ishizaka ${ }^{2}$, Akane Ikeda ${ }^{3}$, Kazuya Miyagawa ${ }^{4}$, Atsumi Mochida ${ }^{4}$ (D), Hiroshi Takeda ${ }^{4,5}$, \\ Kotaro Takeda ${ }^{6}$ (D) Isato Fukushi ${ }^{7,8}$, Yasumasa Okada ${ }^{8}$ and David Gozal ${ }^{9}$ (D)
}

1 Department of General Medicine, School of Medicine, IUHW Shioya Hospital, International University of Health and Welfare (IUHW), Yaita 329-2145, Japan

2 Department of Physical Therapy, School of Health Science, International University of Health and Welfare, Otawara 324-8501, Japan; ishizaka@iuhw.ac.jp

3 Department of Rehabilitation, IUHW Shioya Hospital, International University of Health and Welfare (IUHW), Yaita 329-2145, Japan; 1012003@g.iuhw.ac.jp

4 Department of Pharmacology, School of Pharmacy, International University of Health and Welfare, Otawara 324-8501, Japan; miyagawa@iuhw.ac.jp (K.M.); atsusaitou@iuhw.ac.jp (A.M.); hirotakeda@iuhw.ac.jp (H.T.)

5 Department of Pharmacology, School of Pharmacy at Fukuoka, International University of Health and Welfare, Okawa 831-8501, Japan

6 Faculty of Rehabilitation, School of Healthcare, Fujita Health University, Toyoake 470-1192, Japan; ktakeda@fujita-hu.ac.jp

7 Faculty of Health Sciences, Uekusa Gakuen University, Chiba 264-0007, Japan; fukushi@1998.jukuin.keio.ac.jp

8 Laboratory of Electrophysiology, Clinical Research Center, Murayama Medical Center,

check for

Citation: Umeda, A.; Ishizaka, M.; Ikeda, A.; Miyagawa, K.; Mochida, A.; Takeda, H.; Takeda, K.; Fukushi, I.; Okada, Y.; Gozal, D. Recent Insights into the Measurement of Carbon Dioxide Concentrations for Clinical Practice in Respiratory Medicine. Sensors 2021, 21, 5636. https:// doi.org/10.3390/s21165636

Academic Editors: Vincenzo Spagnolo and Jesús M. Corres

Received: 26 June 2021

Accepted: 16 August 2021

Published: 21 August 2021

Publisher's Note: MDPI stays neutral with regard to jurisdictional claims in published maps and institutional affiliations.

Copyright: (c) 2021 by the authors. Licensee MDPI, Basel, Switzerland. This article is an open access article distributed under the terms and conditions of the Creative Commons Attribution (CC BY) license (https:/ / creativecommons.org/licenses/by/ $4.0 /)$.
Musashimurayama 208-0011, Japan; yasumasaokada@1979.jukuin.keio.ac.jp

9 Department of Child Health and the Child Health Research Institute, MU Women's and Children's Hospital, University of Missouri, Columbia, MO 65201, USA; gozald@health.missouri.edu

* Correspondence: umeda@iuhw.ac.jp; Tel.: +81-2-8744-1155

\begin{abstract}
In the field of respiratory clinical practice, the importance of measuring carbon dioxide $\left(\mathrm{CO}_{2}\right)$ concentrations cannot be overemphasized. Within the body, assessment of the arterial partial pressure of $\mathrm{CO}_{2}\left(\mathrm{PaCO}_{2}\right)$ has been the gold standard for many decades. Non-invasive assessments are usually predicated on the measurement of $\mathrm{CO}_{2}$ concentrations in the air, usually using an infrared analyzer, and these data are clearly important regarding climate changes as well as regulations of air quality in buildings to ascertain adequate ventilation. Measurements of $\mathrm{CO}_{2}$ production with oxygen consumption yield important indices such as the respiratory quotient and estimates of energy expenditure, which may be used for further investigation in the various fields of metabolism, obesity, sleep disorders, and lifestyle-related issues. Measures of $\mathrm{PaCO}_{2}$ are nowadays performed using the Severinghaus electrode in arterial blood or in arterialized capillary blood, while the same electrode system has been modified to enable relatively accurate non-invasive monitoring of the transcutaneous partial pressure of $\mathrm{CO}_{2}\left(\mathrm{PtcCO}_{2}\right)$. $\mathrm{PtcCO}_{2}$ monitoring during sleep can be helpful for evaluating sleep apnea syndrome, particularly in children. End-tidal $\mathrm{PCO}_{2}$ is inferior to $\mathrm{PtcCO}_{2}$ as far as accuracy, but it provides breath-by-breath estimates of respiratory gas exchange, while $\mathrm{PtcCO}_{2}$ reflects temporal trends in alveolar ventilation. The frequency of monitoring end-tidal $\mathrm{PCO}_{2}$ has markedly increased in light of its multiple applications (e.g., verify endotracheal intubation, anesthesia or mechanical ventilation, exercise testing, respiratory patterning during sleep, etc.).
\end{abstract}

Keywords: carbon dioxide; transcutaneous partial pressure; end-tidal partial pressure; Bland-Altman analysis; blood gas analysis

\section{Introduction}

Atmospheric carbon dioxide $\left(\mathrm{CO}_{2}\right)$ concentration is increasing worldwide by the increasing consumption of carbon-based combustibles along with progressive deforestation $[1,2]$. Increases in atmospheric $\mathrm{CO}_{2}$ concentrations are thought to cause elevation 
of atmospheric temperature as a result of the greenhouse effect. High concentrations of atmospheric $\mathrm{CO}_{2}$ can facilitate the onset of human health problems, such as increased fatigue, headache, and tinnitus. Inhalation of $0.1 \% \mathrm{CO}_{2}$ for a short time has been reported to cause marked changes in respiratory, circulatory, and cerebral electrical activity $[3,4]$. More recently, continuous measurements of atmospheric $\mathrm{CO}_{2}$ concentrations have been viewed as being helpful for the evaluation of ventilation conditions in rooms or buildings, and it has been utilized as guidance to avoid the transmission of severe acute respiratory syndrome coronavirus 2 (SARS-CoV-2) [5]. SARS-CoV-2 can cause the coronavirus disease 2019 (COVID-19), which has emerged as a serious problem in respiratory clinical practice [6-8].

On the other hand, arterial blood gas analysis (ABGA) is very commonly implemented in routine clinical practice of respiratory medicine [9-11]. Arterial partial pressure of $\mathrm{CO}_{2}$ $\left(\mathrm{PaCO}_{2}\right)$ is commonly evaluated in any type of respiratory disease. $\mathrm{PaCO}_{2}$ is useful for the diagnosis of hypo- or hyperventilation and to evaluate potential respiratory drive depression and $\mathrm{CO}_{2}$ narcosis in patients with chronic obstructive pulmonary disease (COPD) or other conditions. The evaluation of acid-base imbalance in the context of respiratory acidosis can be performed using $\mathrm{pH}$ and $\mathrm{PaCO}_{2}$ data. Non-invasive alternative methods such as end-tidal $\mathrm{CO}_{2}$ partial pressure of exhaled gas $\left(\mathrm{PetCO}_{2}\right)$ and transcutaneous partial pressure of $\mathrm{CO}_{2}\left(\mathrm{PtcCO}_{2}\right)$ have been developed, and their accuracy and usefulness have been evaluated by Bland-Altman analysis [12].

Another use of $\mathrm{CO}_{2}$ concentration measurements in exhaled air involves assessment of $\mathrm{CO}_{2}$ production [9]. The respiratory quotient (RQ) can be calculated using the data of $\mathrm{CO}_{2}$ production $\left(\dot{\mathrm{VCO}}_{2}\right)$ and oxygen $\left(\mathrm{O}_{2}\right)$ consumption $\left(\dot{\mathrm{VO}}_{2}\right)$. Then, the difference of partial pressure of oxygen $\left(\mathrm{PO}_{2}\right)$ between mean alveolar gas and arterial blood can be calculated [10]. This approach has been used for the evaluation of gas exchange impairment in various lung diseases $[9,10,13]$. Energy expenditure can be also evaluated, and this is particularly of interest in obese patients with obstructive sleep apnea syndrome (OSAS) using $\mathrm{CO}_{2}$ production data and oxygen consumption data [14].

Thus, depending on the objectives driving the measurement of $\mathrm{CO}_{2}$ concentrations, the most suitable method should be adopted. In order to better understand the considerations involved in such choices, we will discuss the principles, sensitivity, and limitations of the various methods available for measuring $\mathrm{CO}_{2}$ concentrations.

\section{Atmospheric Carbon Dioxide Concentration}

The World Data Centre for Greenhouse Gases reported that atmospheric $\mathrm{CO}_{2}$ concentrations are increasing worldwide, and they are currently around 410 ppm (Figure 1) [2]. The method to measure this concentration is by non-dispersive infrared technology (Figure 2) [15-18]. This increase in $\mathrm{CO}_{2}$ level has been mainly attributed to increasing the consumption of carbon-based energy sources (e.g., coal, oil) with significant concomitant deforestation due to unregulated expansion of industrial agriculture initiatives [1,2].

When atmospheric $\mathrm{CO}_{2}$ concentration rises, human $\mathrm{PaCO}_{2}$ will rise, but its toxicity has been reported to be little, if any, at 5\% (50,000 ppm) or lower [19]. Atmospheric $\mathrm{CO}_{2}$ concentrations of more than 50,000 ppm may cause hypercapnia, respiratory acidosis, and increased respiratory rate. Severe acidosis will ultimately result in depression of the respiration and the circulation. Atmospheric $\mathrm{CO}_{2}$ concentrations of more than $10 \%$ (100,000 ppm) may cause convulsions, coma, and death [19].

Duarte et al. showed the standard $\mathrm{CO}_{2}$ levels in air in indoors environments (i.e., $>15,000$ ppm: accident by $\mathrm{CO}_{2}$ intoxication; 10,000 ppm: submarines; 5000 ppm: crowded indoors; 600 ppm: well-ventilated indoors) [20].

According to the documents of the World Health Organization, the amplitude (depth) of respiratory movements was reduced by the inhalation of $0.1 \%$ (1000 ppm) $\mathrm{CO}_{2}$, while peripheral blood flow was increased, and the amplitude of brain electrical waves was increased [3,4]. In these documents from the 1960s, it was suggested that the indoors concentrations of $\mathrm{CO}_{2}$ should not exceed 1000 ppm. A man engaged in light work exhales 
about 22.6 $\mathrm{L}$ of $\mathrm{CO}_{2}$ per hour [4], and since the recent normal concentration of $\mathrm{CO}_{2}$ in the atmosphere is $0.04 \%\left(0.4 \mathrm{~L} / \mathrm{m}^{3}\right)$, the volume of required fresh air per person to ensure $\mathrm{CO}_{2}$ concentrations not exceeding $0.1 \%\left(1.0 \mathrm{~L} / \mathrm{m}^{3}\right)$ would be $22.6 /(1.0-0.4)=38 \mathrm{~m}^{3}$ per hour. Thus, strict monitoring of air circulation and $\mathrm{CO}_{2}$ concentrations are essential in indoor locations where the density of humans is high (e.g., cinemas, theaters, office buildings, hospitals, etc.).

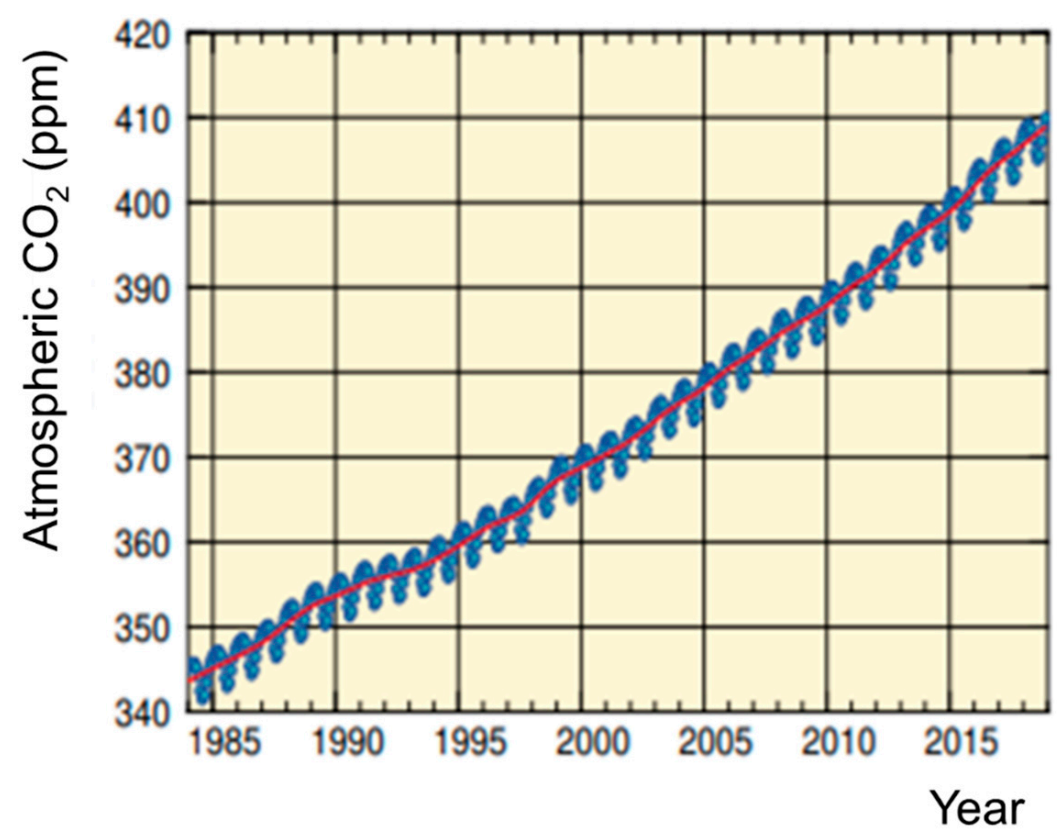

Figure 1. Globally averaged monthly mean mole fraction of $\mathrm{CO}_{2}$ from 1984 to 2018 and the deseasonalized long-term trend shown as a red line (Adapted with permission from Ref. [2]. Copyright 2020 WMO WDCGG).

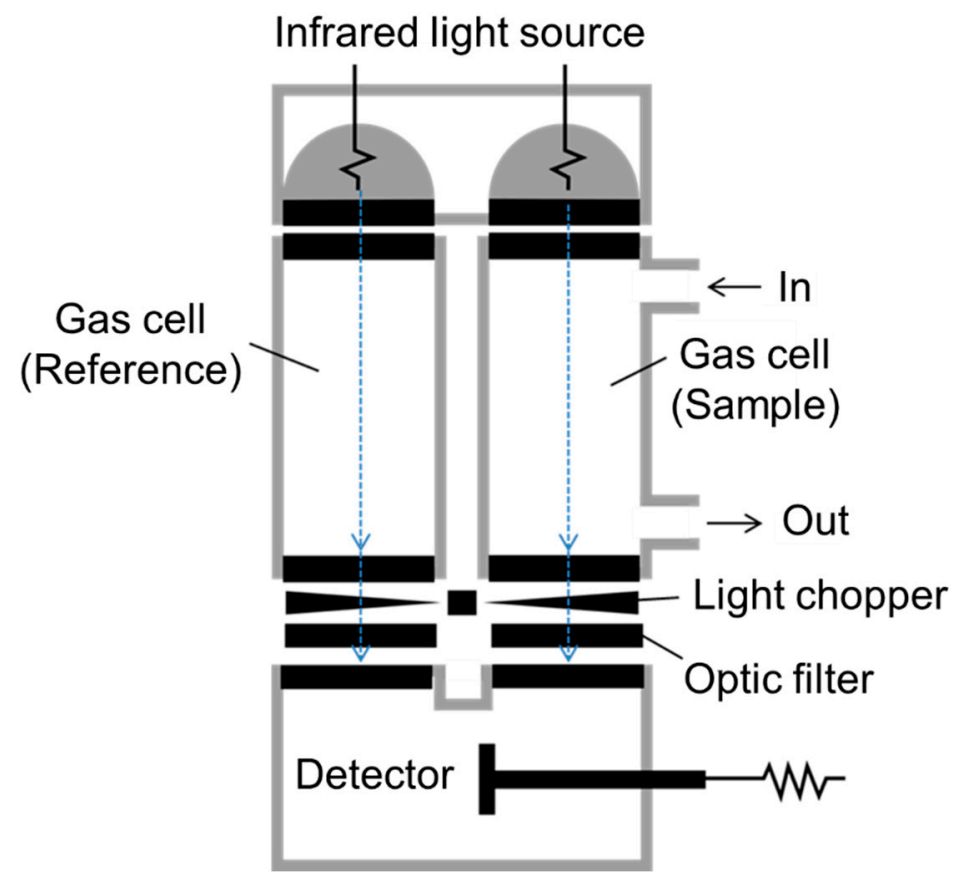

Figure 2. Measuring system of $\mathrm{CO}_{2}$ by using the non-dispersive infrared analyzer. The light chopper delivers the data of infrared intensity as a continuous alternating current signal to the detector through the optic filter (Adapted with permission from Ref. [18]. Copyright 2021 HORIBA). 
Measuring atmospheric $\mathrm{CO}_{2}$ concentrations has been helpful for evaluation of the ventilation conditions in rooms of buildings aiming to decrease the transmission risk of SARS-CoV-2, which can cause COVID-19 (Figure 3) [5,21,22]. Smaller droplets $(<10 \mu \mathrm{m})$ with SARS-CoV-2 content expired from COVID-19 patients can travel tens of meters in the air while indoors and cause airborne transmission [23,24]. The Japanese government recommended the use of atmospheric $\mathrm{CO}_{2}$ sensors in rooms such as restaurants in order to prevent COVID-19 especially in cold weather [25]. Guidelines for indoor $\mathrm{CO}_{2}$ concentrations to reduce indoors COVID-19 infection risk should be more helpful if they account for environment and activity types [5]. Marr et al. suggested that indoor $\mathrm{CO}_{2}$ concentrations should not exceed 700 ppm in classrooms and 550 ppm in hallways in order to limit the COVID-19 transmission in schools [26]. Teachers in many countries may be required to keep the indoor $\mathrm{CO}_{2}$ concentrations low and decrease the students' risk of inhaling SARS$\mathrm{CoV}-2$ floating in the air in classrooms. By measuring indoor $\mathrm{CO}_{2}$ concentrations, teachers can evaluate how widely the windows should be opened (e.g., fully or partially open) in classrooms considering the meteorological conditions (especially wind) and estimate the overall rate of ventilation in the classroom [26].

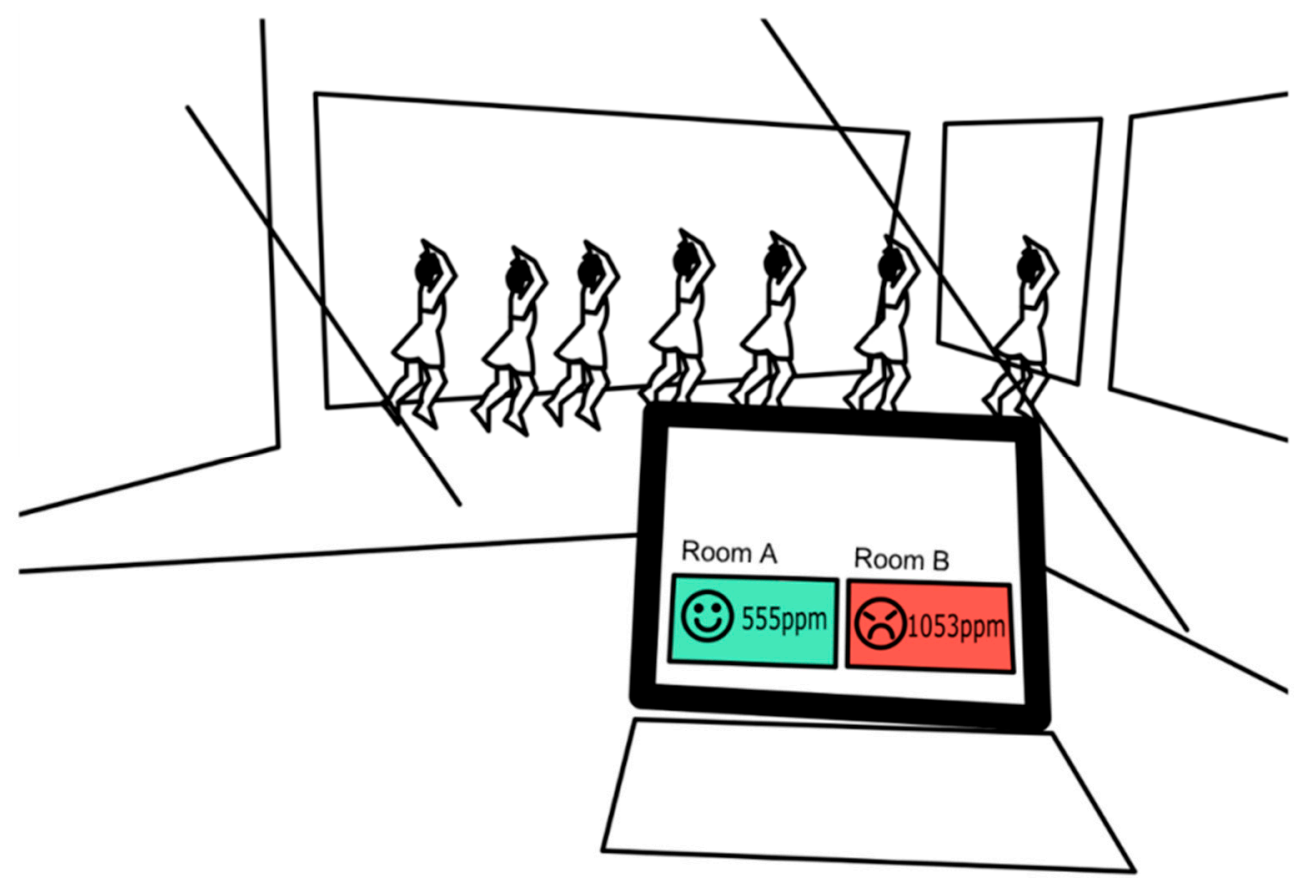

Figure 3. Monitoring of $\mathrm{CO}_{2}$ levels in rooms. Higher levels of $\mathrm{CO}_{2}$ in a room can mean there is a greater risk of viral transmission (Adapted with permission from Ref. [21]. Copyright 2020 Kyodo).

In addition, there was a fatal accident involving $\mathrm{CO}_{2}$ fire extinguishing equipment in Japan in April 2021 [27]. Four people died and two people were injured due to the high concentrations of $\mathrm{CO}_{2}$ because the equipment in the basement parking garage was mistakenly activated. The mandate of monitoring atmospheric $\mathrm{CO}_{2}$ concentration is increasing and is likely to become mandatory in buildings and similar public structures. Currently, the measurement of $\mathrm{CO}_{2}$ concentrations using infrared is the fastest method to obtain data from atmospheric samples at low cost; as such, this method is suitable in most of the situations.

\section{Blood Gas Analysis: Principle of $\mathrm{PaCO}_{2}$ Electrode}

Apart from atmospheric $\mathrm{CO}_{2}$ concentration measures, it is frequently necessary to measure the partial pressure of $\mathrm{CO}_{2}\left(\mathrm{PCO}_{2}\right)$ in blood in respiratory clinical practice. The analysis of blood gas values has been performed by means of electrochemical devices [28]. The traditionally used electrode for measuring $\mathrm{PCO}_{2}$ is termed the Severinghaus $\mathrm{PCO}_{2}$ electrode, per the last name of the inventor of this electrode, Dr. John Severinghaus 
(Figure 4) $[28,29]$. This $\mathrm{PCO}_{2}$ electrode contains the $\mathrm{CO}_{2}$-permeable membrane and the principle of $\mathrm{pH}$ meter with a $\mathrm{pH}$-sensitive glass membrane. $\mathrm{PaCO}_{2}$ is usually measured for the evaluation of any type of lung disease $[9,10] . \mathrm{PaCO}_{2}$ is useful for the diagnosis of hyperventilation, hypoventilation, $\mathrm{CO}_{2}$ retention, and $\mathrm{CO}_{2}$ narcosis in patients with $\mathrm{COPD}$ and many other pulmonary conditions $[10,30,31]$.

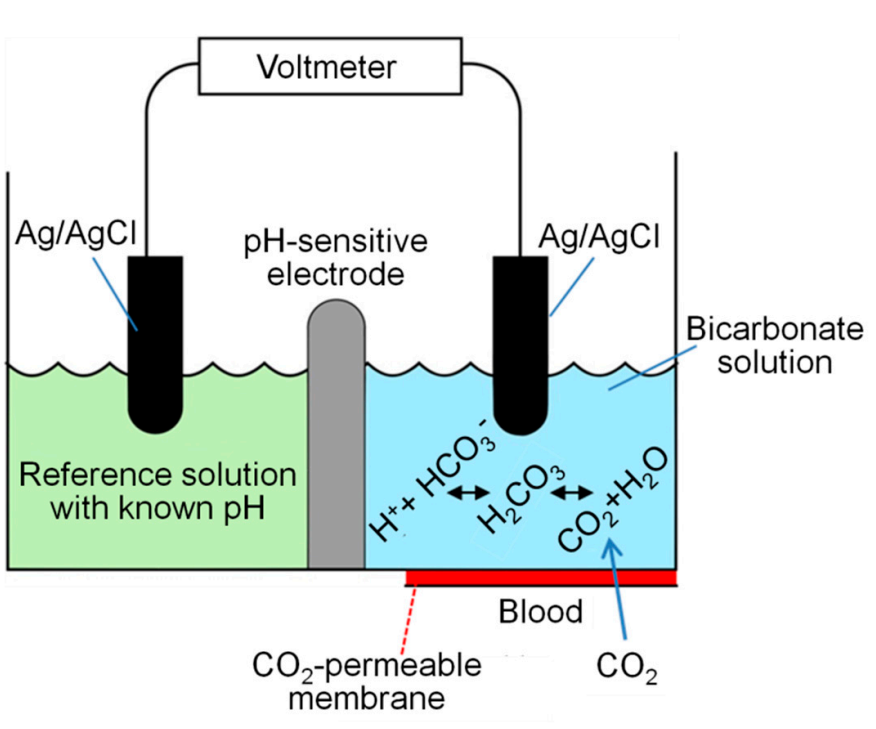

(a)

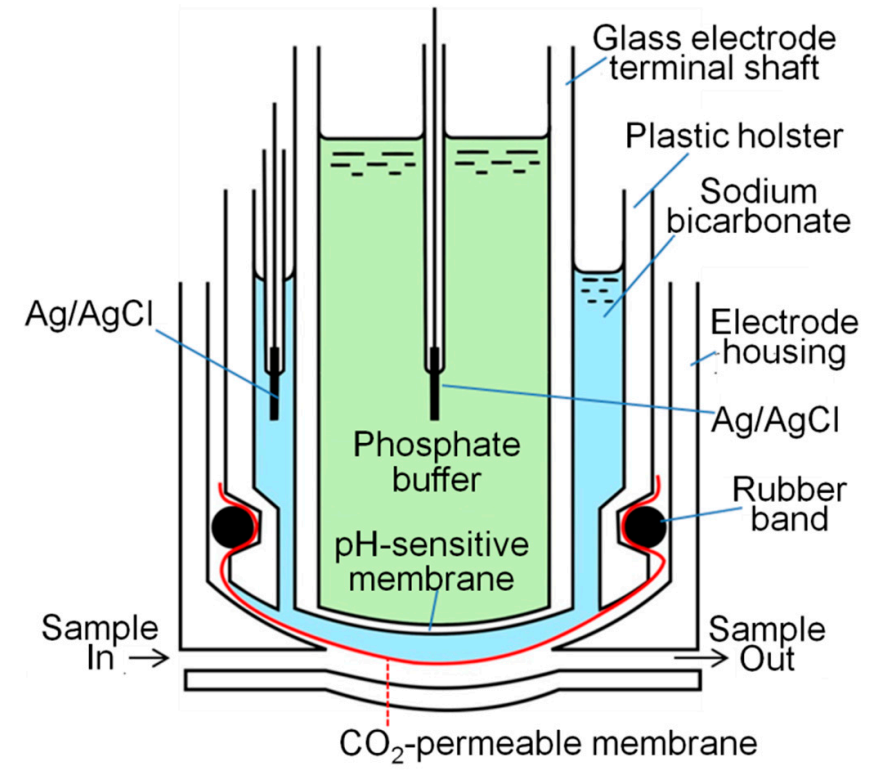

(b)

Figure 4. $\mathrm{PCO}_{2}$ electrode. (a) The $\mathrm{CO}_{2}$ from the blood diffuses through the membrane (red) into the bicarbonate solution (light blue). The hydrolysis reaction occurs in the bicarbonate solution and results in the production of hydrogen ions $\left(\mathrm{H}^{+}\right)$in proportion to the amount of dissolved $\mathrm{CO}_{2}$ present. The difference in voltage between the reference solution (light green) and the bicarbonate solution (light blue) is measured. $\mathrm{Ag} / \mathrm{AgCl}$, Silver electrode plated with silver chloride; $\mathrm{HCO}_{3}{ }^{-}$, Bicarbonate ion; $\mathrm{H}_{2} \mathrm{CO}_{3}$, Carbonic acid (Adapted with permission from Ref. [28]. Copyright 2005 Elsevier). (b) Severinghaus $\mathrm{PCO}_{2}$ electrode. The principle of $\mathrm{pH}$ meter with $\mathrm{pH}$-sensitive glass membrane is used (Adapted with permission from Ref. [28]. Copyright 2005 Elsevier).

The evaluation of acid-base imbalance (i.e., respiratory acidosis, respiratory alkalosis, metabolic acidosis, and metabolic alkalosis), with the consideration of compensation, can be performed using simultaneous arterial $\mathrm{pH}$ and $\mathrm{PaCO}_{2}$ measurements [32,33]. The majority of $\mathrm{CO}_{2}$ is transported in the body as bicarbonate ion $\left(\mathrm{HCO}_{3}{ }^{-}\right)$[34]. $\mathrm{HCO}_{3}{ }^{-}$plays a central role in maintaining the $\mathrm{pH}$ level in blood [32-34]. Therefore, it is important to calculate its concentration $\left(\left[\mathrm{HCO}_{3}{ }^{-}\right]\right)$in blood using the Henderson-Hasselbalch equation. $\left[\mathrm{HCO}_{3}{ }^{-}\right]$is calculated using the following equation on devices such as Rapidlab 1265 (Siemens Healthcare Diagnostics, Sudbury, UK).

$$
\left[\mathrm{HCO}_{3}{ }^{-}\right]=0.0307 \times \mathrm{PCO}_{2} \times 10^{(\mathrm{pH}-6.105)}
$$

The normal ranges for $\mathrm{PaCO}_{2}$, arterial $\mathrm{pH}$, and arterial $\left[\mathrm{HCO}_{3}{ }^{-}\right]$are $35-45 \mathrm{mmHg}$, 7.35-7.45, and 22-26 mEq/L, respectively [35]. These data are useful for the calculation of anion gap (AG) $[32,34,36]$. Using the plasma sodium concentration $\left(\left[\mathrm{Na}^{+}\right]\right)$and plasma chloride concentration $\left(\left[\mathrm{Cl}^{-}\right]\right), \mathrm{AG}$ is calculated by the following equation.

$$
\mathrm{AG}=\left[\mathrm{Na}^{+}\right]-\left(\left[\mathrm{Cl}^{-}\right]+\left[\mathrm{HCO}_{3}^{-}\right]\right)
$$

The normal range for AG is 6-12 mmol/L [32]. AG is utilized for the differential diagnosis of metabolic acidosis. High-AG metabolic acidosis due to increased fixed acid includes ketoacidosis, lactic acidosis, renal failure, toxin by salicylates, etc. [32,34,36]. 
Normal-AG metabolic acidosis includes renal tubular acidosis, $\mathrm{HCO}_{3}{ }^{-}$loss from the gastrointestinal tract, etc. [32,34,36].

The usual clinical practice for ABGA in conscious patients involves a single arterial puncture; however, the procedure may cause pain and cause hyperventilation [11]. $\mathrm{PaCO}_{2}$ via the arterial puncture performed after a resting period of 20-30 $\mathrm{min}$ has been understood as the gold standard, because arterial blood samples must be drawn when the patient is in a steady state [11,37]. Therefore, newly developed surrogates should be compared with this gold standard $\mathrm{PaCO}_{2}$ data.

$\mathrm{PaCO}_{2}$ is also useful for the evaluation of the ventilatory support being provided to patients with respiratory insufficiency [38]. However, an arterial puncture is necessary for measuring $\mathrm{PaCO}_{2}$, and it is sometimes difficult and painful, e.g., for pediatric patients. Therefore, less invasive or non-invasive surrogate measurements have been sought, and they include venous or capillary partial pressure of $\mathrm{CO}_{2}, \mathrm{PetCO}_{2}$, and $\mathrm{PtcCO}_{2}$.

\section{Non-Invasive Alternative Methods to Estimate $\mathrm{PaCO}_{2}$}

\subsection{Venous Blood Gas Analysis (VBGA)}

The pulse oximeter allows the measurement of the levels of systemic $\mathrm{O}_{2}$ by determining the degree of percutaneous $\mathrm{O}_{2}$ saturation $\left(\mathrm{SpO}_{2}\right)[39,40]$. Therefore, peripheral VBGA with simultaneous evaluation of $\mathrm{SpO}_{2}$ offers an alternative to arterial blood gas analysis [41-43]. This approach has become standard practice, particularly among pediatric patients and in the emergency department, owing to its advantages (i.e., easiness and less invasive nature) over arterial blood gas analysis [44-46]. Capillary blood gas analysis can also be performed. This is particularly useful in children and involves warming the extremity to arterialize the subcutaneous vascular bed and extracting a minute amount of blood using a lancet. The gas content of this sample should be similar to the values obtained for actual arterial blood samples [47-49]. It has been demonstrated that intentional hyperventilation increases venous-arterial $\mathrm{PCO}_{2}$ differences and $\mathrm{pH}$ differences [50]. Moreover, in patients with respiratory alkalosis who did not receive treatment, the condition may be underestimated by the "SpO 2 plus VBGA" method [50]. Furthermore, hyperventilation increases differences in the concentration of venous-arterial bicarbonate [51]. Therefore, these changes may be attributed to a reduction in peripheral blood perfusion induced by hyperventilation-associated systemic vasoconstriction [50,51].

\subsection{End-Tidal $\mathrm{PCO}_{2}$}

Traditionally, the concentration of $\mathrm{CO}_{2}$ in an exhaled gas is calculated by determining the levels of chemically absorbed $\mathrm{CO}_{2}$ and other gases [52-54]. The absorbed $\mathrm{CO}_{2}$ is subsequently compared with the total volume of the gas, thereby revealing the levels of $\mathrm{CO}_{2}$ present. The concentration of $\mathrm{CO}_{2}$ in an exhaled gas can also be measured by gas chromatography and/or mass spectrometry, but these systems are voluminous, sturdy, and expensive [55-57]. The technological advancement of exhaled $\mathrm{CO}_{2}$ monitoring has enabled the reduction of system size and the adequate monitoring of ventilation using the infrared analyzer. PetCO $\mathrm{O}_{2}$ is the highest and closest estimate of $\mathrm{PaCO}_{2}$ in the time course of continuous sampling of expiratory $\mathrm{PCO}_{2}$ data $[54,58]$. Typically, $\mathrm{PaCO}_{2}$ and $\mathrm{PetCO}_{2}$ differ by $2-5 \mathrm{mmHg}$. However, the presence of lung disease, such as acute respiratory distress syndrome, COPD, and asthma, ventilation/perfusion ( $\dot{\mathrm{V}} / \dot{\mathrm{Q}})$ mismatch (especially relative increase in high $\dot{\mathrm{V}} / \dot{\mathrm{Q}}$ regions) in the lungs can cause the $\mathrm{PaCO}_{2}-\mathrm{PetCO}_{2}$ difference to increase, in which case the non-invasive measurements may be potentially misleading. Patients with gas exchange impairments may be unable to efficiently exhale $\mathrm{CO}_{2}$. Therefore, $\mathrm{PetCO}_{2}$ is not a good surrogate of $\mathrm{PaCO}_{2}$ for patients with pulmonary diseases. Furthermore, $\mathrm{PetCO}_{2}$ cannot replace $\mathrm{PaCO}_{2}[58,59]$. Nevertheless, $\mathrm{PetCO}_{2}$ has been reported to be a useful indicator of pulmonary perfusion and cardiac output during cardiopulmonary resuscitation [54,58-60], and its use was recommended by numerous guidelines (American Heart association [61], European Resuscitation Council [62], and American College of Emergency Physicians [63]). Particularly, the use of waveform capnography was recommended 
during cardiopulmonary resuscitation $[59,61,62]$. The return of spontaneous circulation is indicated by a sudden continuous rise in $\mathrm{PetCO}_{2}(\geq 40 \mathrm{mmHg})$ [61]. Patients with an average $\mathrm{PetCO}_{2}$ of $15 \mathrm{mmHg}$ are more likely to be successfully resuscitated than those with a value of $7 \mathrm{mmHg}$ [64]. In patients with a low or decreasing $\mathrm{PetCO}_{2}$, reassessment of cardiopulmonary resuscitation is recommended [61]. In adults and children, capnometry or capnography can be utilized to continuously monitor alterations in exhaled $\mathrm{CO}_{2}$ from the onset of intubation to extubation $[54,58,65,66]$. Both $\mathrm{PetCO}_{2}$ and $\left(\mathrm{PaCO}_{2}-\mathrm{PetCO}_{2}\right)$ are useful for monitoring $\dot{\mathrm{V}} / \dot{\mathrm{Q}}$ mismatch especially (physiologic deadspace)/(tidal volume) evaluation, and useful to assess pulmonary embolism [58,59]. PetCO $\mathrm{O}_{2}$ monitoring is a faster indicator than pulse oximetry or ECG tracing in order to find patient mishaps such as a ventilator becoming disconnected or other catastrophic events [58].

Monitoring with capnography is recommended not only in intubated patients but also in non-intubated patients undergoing non-invasive positive pressure ventilation (NPPV) [67]. Figure 5 shows the new $\mathrm{CO}_{2}$ sensor, TG-980P (Nihon Kohden, Tokyo, Japan) and a mask, cap-ONE (Nihon Kohden, Tokyo, Japan) in the NPPV system with the recently rolled out ventilator, NKV-330 (Nihon Kohden, Tokyo, Japan). In cap-ONE, the inner cup is included, and exhaled air will efficiently reach TG-980P. Monitoring with capnography is possible at a remote place. The electromechanical response of the new devices for NPPV (NKV-330 with cap-ONE and TG-980P), as shown by breathing on the sensor measuring atmospheric $\mathrm{PCO}_{2}$, elicited an increase in $\mathrm{PCO}_{2}$ within $3 \mathrm{~s}$ even at remote places such as a nurse station in a hospital ward.

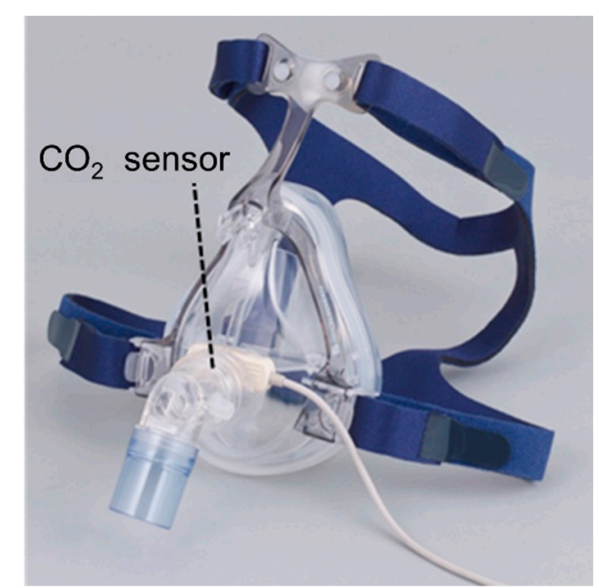

(a)

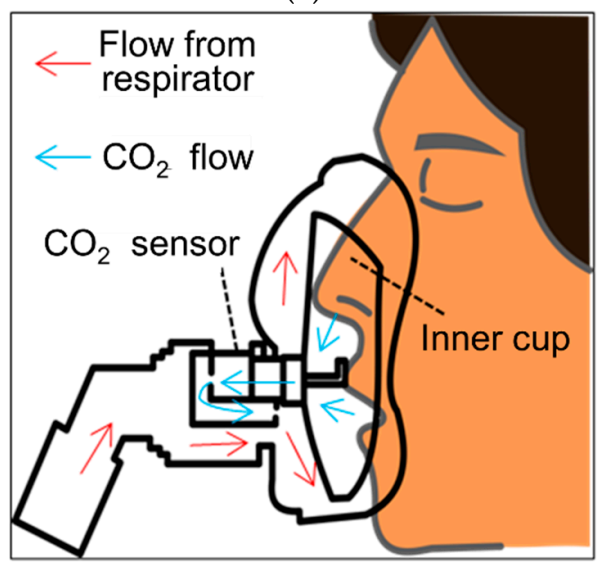

(c)

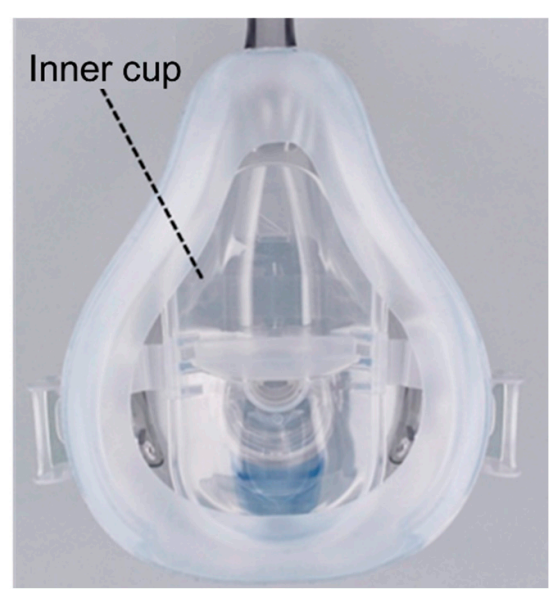

(b)

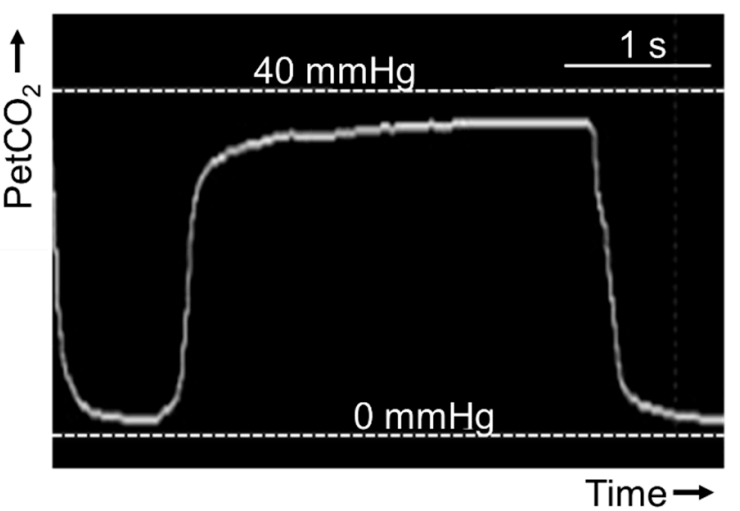

(d)

Figure 5. A system of measuring end-tidal $\mathrm{PCO}_{2}$ during non-invasive positive pressure ventilation. (a) $\mathrm{Mainstream} \mathrm{CO}_{2}$ sensor (TG-980P, Nihon Kohden, Tokyo, Japan) is used in a mask (cap-ONE, Nihon Kohden, Tokyo, Japan). (b) The inner cup is attached inside the mask. (c) Air flow from respirator and exhaled flow from mouth or nose are shown. (d) Capnographic waveform on the monitor of non-invasive positive pressure ventilator (NKV-330, Nihon Kohden, Tokyo, Japan) is shown. 
There are two methods to sample and detect $\mathrm{CO}_{2}$ in clinical situations: mainstream and sidestream $[57,68]$. Mainstream $\mathrm{CO}_{2}$ is measured using a sensor inserted in an airway adapter, and the sample is directly taken from the airway, providing accurate data. Sidestream $\mathrm{CO}_{2}$ is measured by pulling the patient's exhalation air through a small tube into a $\mathrm{CO}_{2}$ detector that is placed at the end of the small tube. Although mainstream $\mathrm{CO}_{2}$ measurement requires a relatively large amount $(150 \mathrm{~mL} / \mathrm{min})$ of sample gas, only a small amount $(50 \mathrm{~mL} / \mathrm{min}$ ) of gas is sufficient for sidestream [68]. Currently, TG-980P is the smallest and the lightest mainstream $\mathrm{PetCO}_{2}$ sensor, where special anti-fog film is used on the window of specimens, and therefore, the heater to avoid fog is unnecessary (Figure 6).

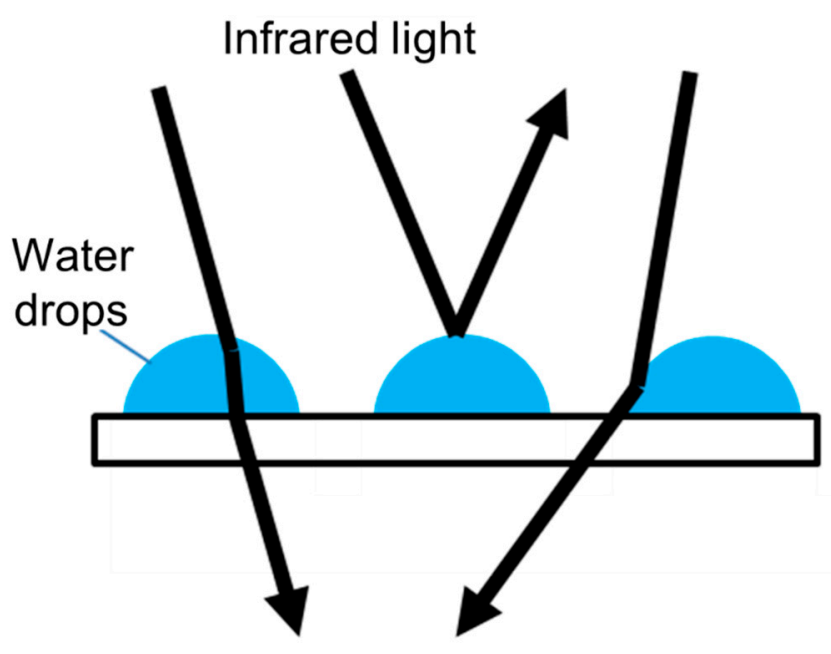

(a)

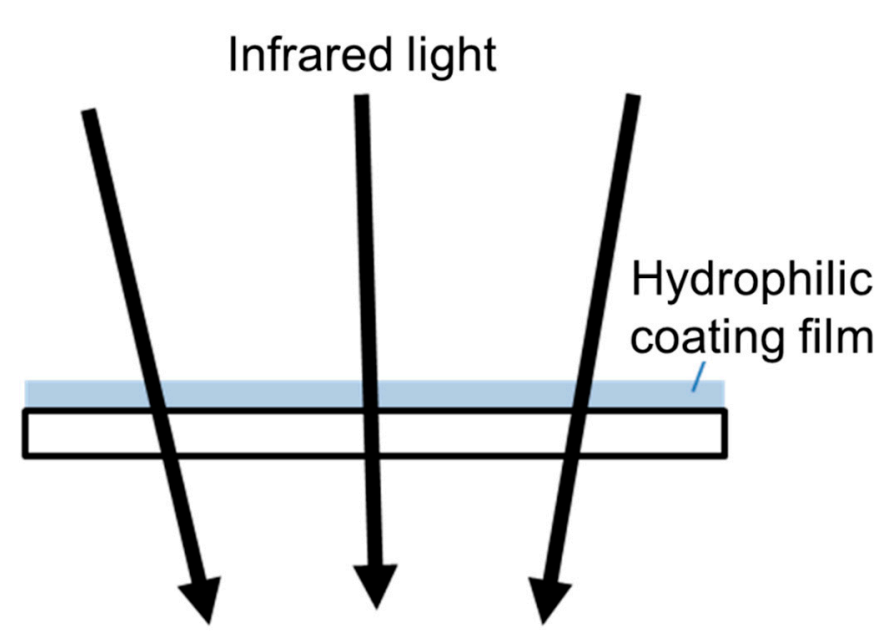

(b)

Figure 6. Technology of size reduction of end-tidal $\mathrm{PCO}_{2}$ sensors. In the new $\mathrm{CO}_{2}$ sensor, the use of heaters to avoid water drops is unnecessary. (a) In ordinary $\mathrm{CO}_{2}$ sensors, heaters are necessary to prevent windows from being clouded by water vapor in expired air. Water drops on windows cause refraction and reflection of infrared lights. (b) The hydrophilic coating film used in the new $\mathrm{CO}_{2}$ sensor (TG-980P, Nihon Kohden, Tokyo, Japan) disabled the surface tension of water drops. Thanks to this anti-fog film, the new sensor does not require the use of heaters.

\subsection{Transcutaneous Blood Gas Analysis}

Evaluation of dissolved gases diffusing into the surface of the skin can be used to determine the partial pressure of gases in blood [69-73]. Heating of the skin locally, occasionally accompanied by measurement of transcutaneous $\mathrm{PO}_{2}$, is necessary for determining the $\mathrm{PtcCO}_{2}$. This dilation of vessels increases the flow of arterial blood to the skin capillary bed below the detector, thereby accelerating the diffusion of gas $[69,70,74,75]$ (Figure 7). According to Severinghaus et al., the $\mathrm{PtcCO}_{2}$ electrode contains a relatively large solid silver reference electrode inside the glass $\mathrm{pH}$ sensor, which enhances the transfer of heat from the heater to the skin via the glass $\mathrm{pH}$ electrode $[69,70]$. The presence of an ultra-thin film of buffer electrolyte between the silver and glass appeared to be important. This internal electrolyte contains reference solution (e.g., phosphate buffer) (light green, Figures 4 and 7). The external electrolyte contains bicarbonate solution (light blue, Figures 4 and 7). The precise blueprints of recent $\mathrm{PtcCO}_{2}$ sensors are different according to manufacturing companies. This approach is commonly used to evaluate the pulmonary gas exchange function in pediatric patients as well as in adults with acute/chronic respiratory failure [76-78]. Moreover, this methodology can be employed to monitor patients receiving mechanical ventilation and managing limb ischemia [79-81]. 


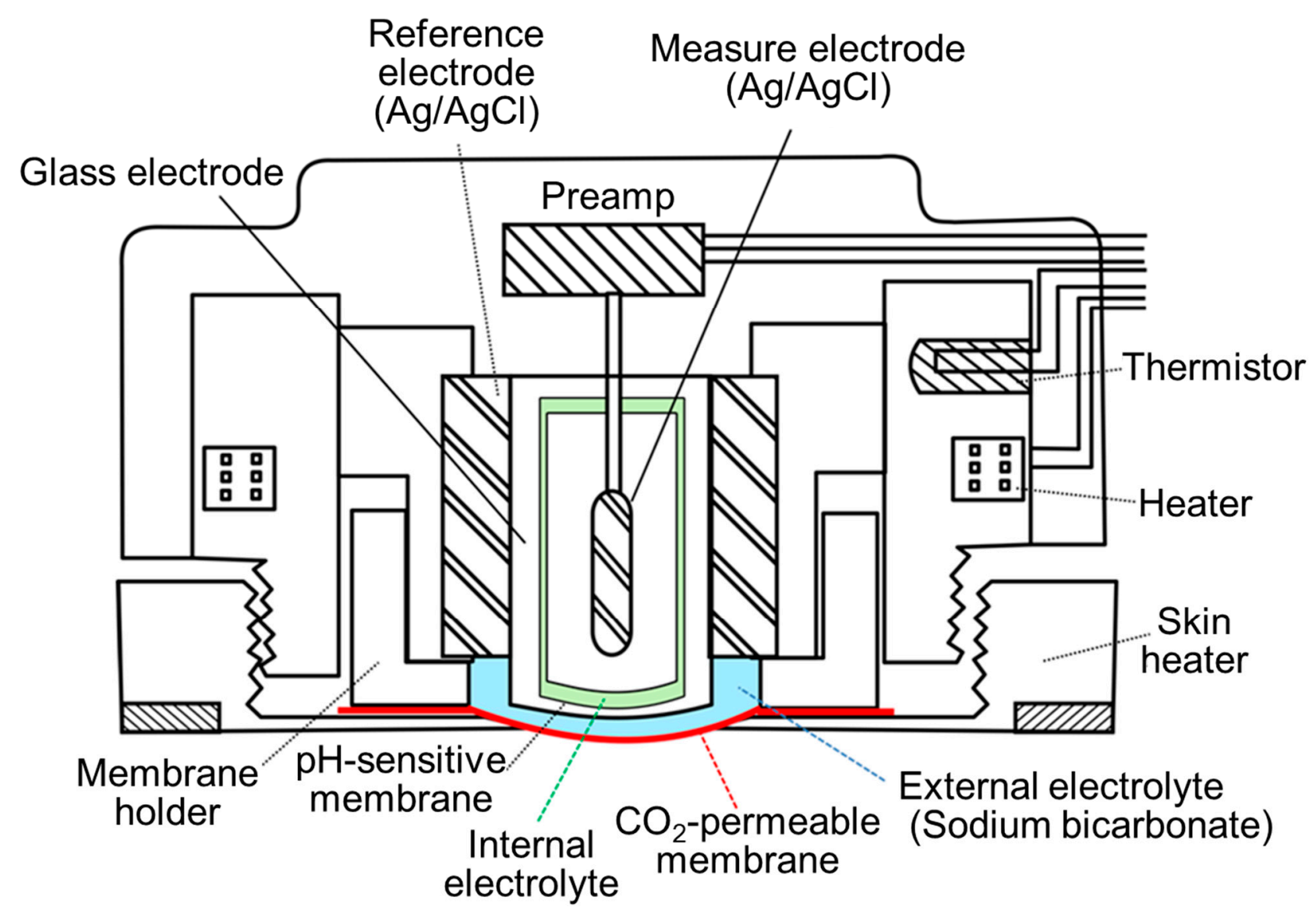

Figure 7. Transcutaneous $\mathrm{PCO}_{2}$ sensor. The skin heater is necessary in addition to the Severinghaus electrode (Adapted with permission from Ref. [73]. Copyright 1983 Japanese Society for Medical and Biological Engineering). An ultra-thin film of buffer electrolyte (light green) is placed between the silver and glass. This internal electrolyte stabilizes the $\mathrm{pH}$ inside the glass electrode. The external electrolyte (light blue) contains sodium bicarbonate. According to the manufacturing companies, the precise blueprints of recent products differ.

\subsection{Comparison of Accuracy}

The accuracy of an alternative new method has been evaluated by Bland-Altman analysis for use in respiratory clinical practice (Table 1) [12,45,50,82-89].

Table 1. Alternative non-invasive methods for measuring $\mathrm{PaCO}_{2}$.

\begin{tabular}{ccccc}
\hline Surrogate & Average Bias & $\mathbf{1 . 9 6 ~ S D}$ & Accuracy & $\begin{array}{c}\text { Usefulness for } \\
\text { Patients with } \\
\text { Pulmonary Diseases }\end{array}$ \\
\hline $\mathrm{PvCO}_{2}$ & $\begin{array}{c}\text { Approximately } 5 \mathrm{mmHg} \\
\text { higher than } \mathrm{PaCO}_{2}\end{array}$ & $\begin{array}{c}14.7-15.0 \mathrm{mmHg} \\
\text { References }\end{array}$ & Worst & Limited \\
\hline $\mathrm{PetCO}_{2}$ & $\begin{array}{c}2-5 \mathrm{mmHg} \text { lower than } \\
\mathrm{PaCO}\end{array}$ & $6.9-14.4 \mathrm{mmHg}$ & Second best & Limited \\
\hline $\mathrm{PtcCO}_{2}$ & $4-5 \mathrm{mmHghigher} \mathrm{than}$ & $4.6-10.4 \mathrm{mmHg}$ & Best & $\begin{array}{c}\text { Good } \\
\text { (still not replaceable) }\end{array}$ \\
\hline
\end{tabular}

$\mathrm{PaCO}_{2}$, arterial partial pressure of $\mathrm{CO}_{2} ; \mathrm{PetCO}$, end-tidal $\mathrm{CO}_{2}$ partial pressure of exhaled gas; $\mathrm{PtcCO}_{2}$, transcutaneous partial pressure of $\mathrm{CO}_{2} ; \mathrm{PvCO}_{2}$, venous partial pressure of $\mathrm{CO}_{2} ; \mathrm{SD}$, standard deviation. The width of $\pm 1.96 \mathrm{SD}$ means the $95 \%$ limits of agreement. 


\section{Usefulness and limitation of Transcutaneous Blood Gas Analysis}

Currently, the most accurate non-invasive alternative surrogate of $\mathrm{PaCO}_{2}$ is $\mathrm{PtcCO}_{2}$ (Table 1). We performed various subgroup analyses on the $\mathrm{PtcCO}_{2}$ bias $\left(\mathrm{PtcCO}_{2}-\mathrm{PaCO}_{2}\right)$ in order to use $\mathrm{PtcCO}_{2}$ efficiently in the future [89].

\subsection{Various Subgroup Analyses on the $\mathrm{PtcCO}_{2}$ Bias}

Subgroup analyses (sex, age, $\mathrm{PaCO}_{2}$ level, and $\mathrm{PaO}_{2}$ level) were performed using the data at $30 \mathrm{~min}$ after the placement of detectors $(n=272)$.

\subsubsection{Sex}

The results of the analysis did not show significant differences in the $\mathrm{PtcCO}_{2}$ bias (males/females: 168/104 [89]).

\subsubsection{Age}

Comparison of the $\mathrm{PtcCO}_{2}$ bias between four age groups: 20-39 years $(\mathrm{n}=11)$; $40-59$ years $(\mathrm{n}=12) ; 60-79$ years $(\mathrm{n}=138)$; and $\geq 80$ years $(\mathrm{n}=111)$ (Figure $8 \mathrm{a})$. The $\mathrm{PtcCO}_{2}$ bias was significantly lower in young adults (20-39 years) versus those aged $40-59$ years and $\geq 80$ years ( $p<0.05$, respectively). $\mathrm{PtcCO}_{2}$ and $\mathrm{PtcO}_{2}$ are frequently utilized in newborns. The increases in $\mathrm{PtcCO}_{2}$ bias induced by aging may be due to the thickness of the skin with increasingly reduced permeability to gas exchange.

\subsection{3. $\mathrm{PaCO}_{2}$ Level}

Comparison of the $\mathrm{PtcCO}_{2}$ bias between the severe hypocapnia group $\left(\mathrm{PaCO}_{2}<\right.$ $31 \mathrm{mmHg} ; \mathrm{n}=7)$, mild hypocapnia group $\left(31 \mathrm{mmHg} \leq \mathrm{PaCO}_{2}<35 \mathrm{mmHg} ; \mathrm{n}=24\right)$, and normal range group $\left(35 \mathrm{mmHg} \leq \mathrm{PaCO}_{2} \leq 45 \mathrm{mmHg} ; \mathrm{n}=202\right.$ ) is shown in Figure $8 \mathrm{~b}$. The $\mathrm{PtcCO}_{2}$ bias was significantly higher in the severe hypocapnia group versus the normal range group $(p<0.01)$, and this was an intensity-dependent effect. Comparison of bias between the normal range group $\left(35 \mathrm{mmHg} \leq \mathrm{PaCO}_{2} \leq 45 \mathrm{mmHg} ; \mathrm{n}=202\right.$ ), mild hypercapnia group ( $45 \mathrm{mmHg}<\mathrm{PaCO}_{2} \leq 50 \mathrm{mmHg} ; \mathrm{n}=26$ ), and severe hypercapnia group ( $50 \mathrm{mmHg}<\mathrm{PaCO}_{2} ; \mathrm{n}=13$ ) is shown in Figure $8 \mathrm{c}$. The $\mathrm{PtcCO}_{2}$ bias was significantly lower in the mild hypercapnia group versus the normal $\mathrm{PaCO}_{2}$ group $(p<0.01)$. The hypocapnic systemic vasoconstriction is thought to be the mechanism of increases in the $\mathrm{PtcCO}_{2}$ bias [50]. $\mathrm{CO}_{2}$ concentration in blood is very important for peripheral blood perfusion. On the other hand, severe hypercapnic subjects $(>50 \mathrm{mmHg}$ ) frequently have comorbid conditions such as circulatory failure, heart failure, edema, infection, etc.

\subsection{4. $\mathrm{PaO}_{2}$ Level}

Comparison of the $\mathrm{PtcCO}_{2}$ bias between the hypoxemia group $\left(\mathrm{PaO}_{2}<80 \mathrm{mmHg}\right.$; $\mathrm{n}=158)$, normal range group ( $\left.80 \mathrm{mmHg} \leq \mathrm{PaO}_{2} \leq 100 \mathrm{mmHg} ; \mathrm{n}=102\right)$, and hyperoxemia group $\left(100 \mathrm{mmHg}<\mathrm{PaO}_{2}, \mathrm{n}=12\right)$ is shown in Figure $8 \mathrm{~d}$. The $\mathrm{PtcCO}_{2}$ bias was significantly lower in the hypoxemia group versus the normal $\mathrm{PaO}_{2}$ group $(p<0.05)$, and this was thought to be a $\mathrm{PaO}_{2}$ level-dependent effect. Previous studies have investigated hypoxemic systemic vasodilation [90]. The concentration of $\mathrm{O}_{2}$ in blood appears to be associated with peripheral perfusion and $\mathrm{PtcCO}_{2}$ bias. 


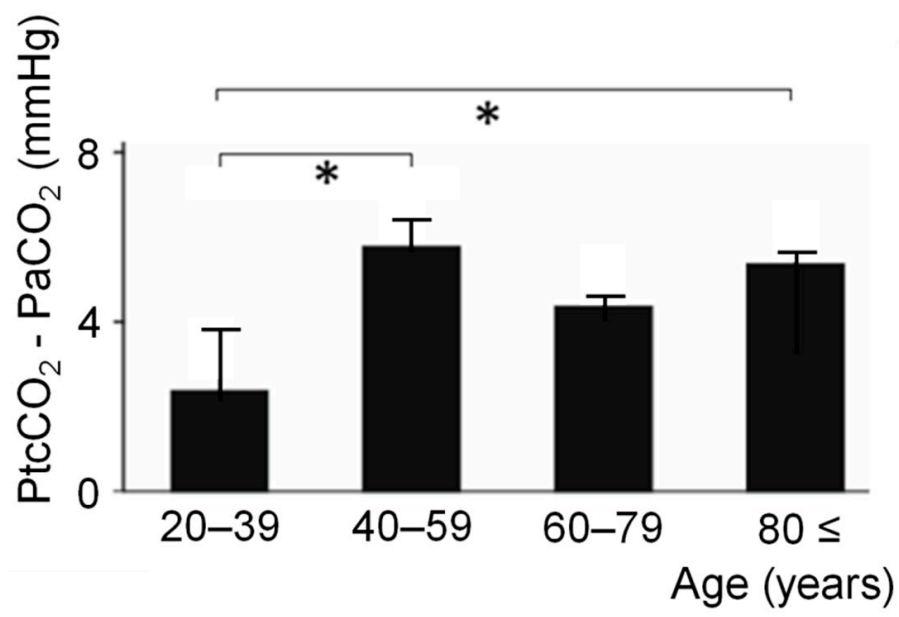

(a)

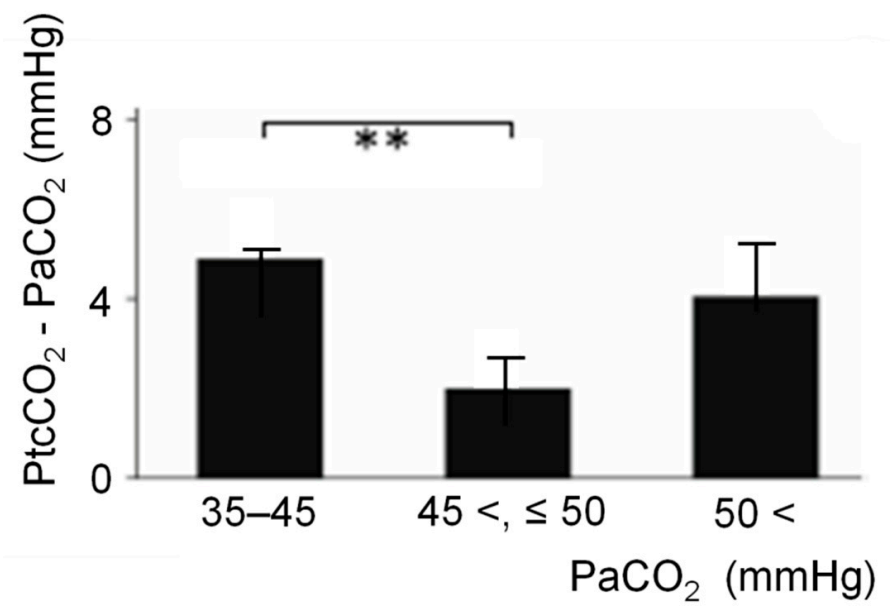

(c)

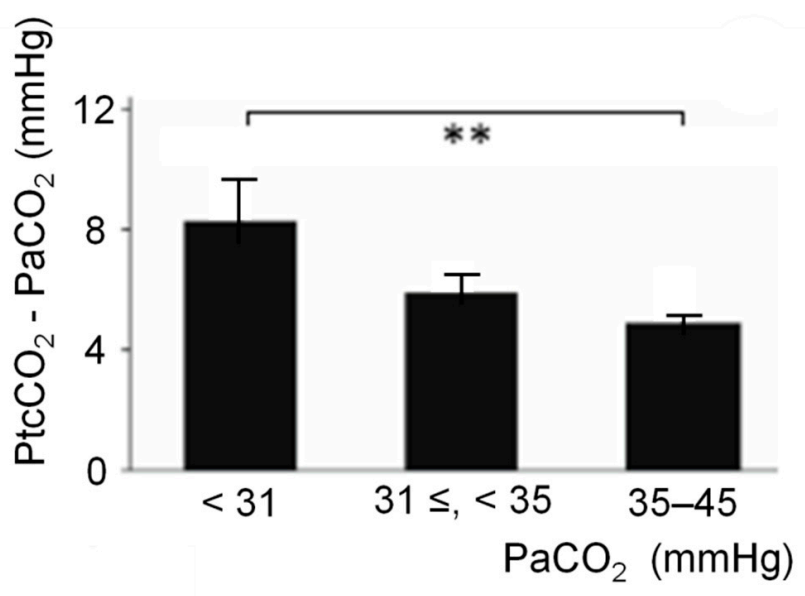

(b)

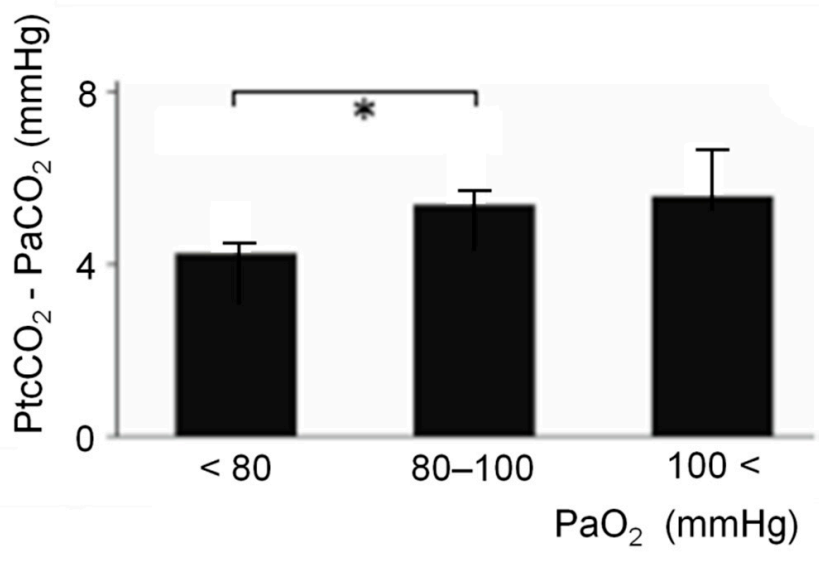

(d)

Figure 8. Comparisons of $\mathrm{PtcCO}_{2}$ and $\mathrm{PaCO}_{2}$ bias $(\mathrm{n}=272)$. (a) Comparison of bias between four age groups. The bias was significantly lower in young adults (20-39 years) versus those aged 40-59 years and $\geq 80$ years. (b) Comparison of bias between the severe, mild hypocapnia group, and normal range group. The bias was significantly higher in the severe hypocapnia group than the normal range group, and this was an intensity-dependent effect. (c) Comparison of bias between the normal range group and mild, severe hypercapnia group. The bias was significantly lower in the mild hypercapnia group versus the normal range group. (d) Comparison of bias between the hypoxemia group, normal range group, and hyperoxemia group. The bias was significantly lower in the hypoxemia group versus the normal range group, and this was a $\mathrm{PaO}_{2}$ level-dependent effect. Bars: SEM, ${ }^{*}: p<0.05,{ }^{* *}: p<0.01$ [89]. $\mathrm{PaCO}_{2}$, arterial partial pressure of $\mathrm{CO}_{2} ; \mathrm{PaO}_{2}$, arterial partial pressure of $\mathrm{O}_{2} ; \mathrm{PCO}_{2}$, partial pressure of $\mathrm{CO}_{2} ; \mathrm{PtcCO}_{2}$, transcutaneous partial pressure of $\mathrm{CO}_{2} ; \mathrm{SEM}$, standard error of the mean.

\subsubsection{Among Various Respiratory Diseases}

There were not significant differences in the $\mathrm{PtcCO}_{2}$ bias among various respiratory diseases in the data of [89] (Figure 9). The breakdown of respiratory diseases was as follows: asthma-COPD overlap $(n=39)$, COPD due to emphysema $(n=25)$, interstitial lung disease $(n=41)$, pneumonia $(n=74)$, asthma $(n=27)$, lung cancer $(n=10)$, acute bronchitis $(n=15)$, bronchiectasis $(n=7)$, sleep apnea syndrome $(n=6)$, pleural diseases $(n=5)$, and others $(\mathrm{n}=15)$. 


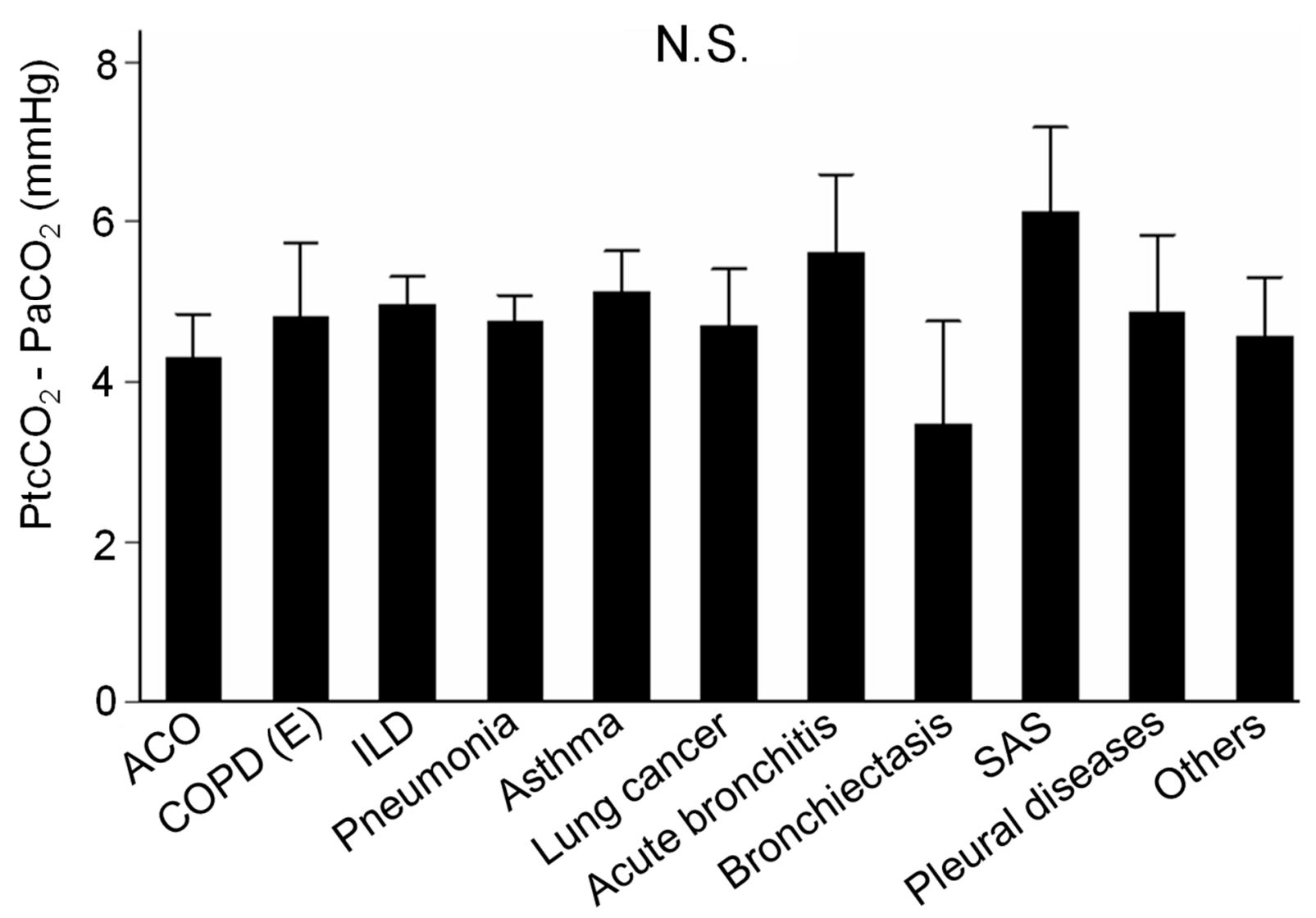

Figure 9. Subgroup analyses on $\mathrm{PCO}_{2}$ bias $\left(\mathrm{PtcCO}_{2}-\mathrm{PaCO}_{2}\right)$ of patients with various respirtory diseases $(\mathrm{n}=272)$. Bars: SEM. There were no significant differences in $\mathrm{PCO}_{2}$ bias (ANOVA with Tukey's post hoc test). ACO, asthma-chronic obstructive pulmonary disease overlap; ANOVA, analysis of variance; COPD, chronic obstructive pulmonary disease; E, emphysema; ILD, interstitial lung disease; N.S., not significant; $\mathrm{PaCO}_{2}$, arterial partial pressure of $\mathrm{CO}_{2} ; \mathrm{PCO}_{2}$, partial pressure of $\mathrm{CO}_{2} ; \mathrm{PtcCO}_{2}$, transcutaneous partial pressure of $\mathrm{CO}_{2} ; \mathrm{SAS}$, sleep apnea syndrome ([89], additional data).

\subsection{Usefulness}

The use of this non-invasive $\mathrm{PtcCO}_{2}$ monitor leads to an accurate assessment of $\mathrm{CO}_{2}$ retention. All hypercapnia patients with $\mathrm{PaCO}_{2}>50 \mathrm{mmHg}(\mathrm{n}=13 \rightarrow 20)$ showed $\mathrm{PtcCO}_{2} \geq 50 \mathrm{mmHg}$ until $12 \mathrm{~min}$ [89] (additional data). Utilization of thinner films for $\mathrm{CO}_{2}$-permeable and/or $\mathrm{pH}$-sensitive membranes (Figure 7) may accelerate the speed to equilibration in order to reach the accurate data. The American Association for Respiratory Care has recommended an acceptable clinical range of agreement between $\mathrm{PtcCO}_{2}$ and $\mathrm{PaCO}_{2}$ ( \pm 1.96 standard deviation: $\pm 7.5 \mathrm{mmHg}$ or narrower) [80]. This range of agreement, determined through TCM4 with a tcSensor 84 (Radiometer Medical AsP, Copenhagen, Denmark), was reduced over time: $\pm 13.6 \mathrm{mmHg}$ at $4 \mathrm{~min}, \pm 7.5 \mathrm{mmHg}$ at $12-13 \mathrm{~min}$, and $\pm 6.3 \mathrm{mmHg}$ at $30 \mathrm{~min}$ [89].

\subsection{Limitations}

Although $\mathrm{PtcCO}_{2}$ is currently the best non-invasive surrogate of $\mathrm{PaCO}_{2}$, there were still some cases with large bias over $10 \mathrm{mmHg}$. $\mathrm{PaCO}_{2}$ cannot be replaced with $\mathrm{PtcCO}_{2}$ completely even after considering the average bias of $4-5 \mathrm{mmHg}$ (Table 1) [89]. Other limitations include the occurrence of technical drift; therefore, the baseline calibration is necessary [91,92]. In addition, rapid results are not available, and the results are not independent of dermal perfusion, edema, or increased skin thickness [91,93].

\subsection{Future Use}

$\mathrm{PtcCO}_{2}$ monitoring during sleep study has been reported to be useful for evaluating the necessity of ventilatory support especially in patients with neuromuscular 
disorders [94,95]. $\mathrm{PtcCO}_{2}$ monitoring with polysomnography may become the standard method of sleep study in the future [94]. $\mathrm{PtcCO}_{2}$ monitoring during rehabilitation may be the promising method, too [96-98]. However, the actual $\mathrm{PaCO}_{2}$ will not be disregarded, because the $\mathrm{PCO}_{2}$ bias is sometimes large, and $\mathrm{PtcCO}_{2}$ cannot replace $\mathrm{PaCO}_{2}$ completely [89]. Therefore, future use of $\mathrm{PtcCO}_{2}$ monitoring will be limited and may be just focusing on relative evolution.

\section{Other Applications of Measuring $\mathrm{CO}_{2}$ Mainly for Research Use}

Measuring $\mathrm{CO}_{2}$ in exhaled gas is also used for assessment of the metabolic condition of subjects. Energy expenditure (EE) is determined using the Weir equation (e.g., MK-5000, Muromachi Kikai, Tokyo, Japan) (Figure 10) [99-101]. RQ is calculated using the pulmonary exchange ratio $\left(\dot{\mathrm{V} C O}{ }_{2} / \dot{\mathrm{VO}}_{2}\right)$

$\mathrm{EE}(\mathrm{kcal} / \mathrm{kg} / \mathrm{h})=\left(3.815 \times \dot{\mathrm{VO}}_{2}\right)+\left(1.232 \times \dot{\mathrm{V} C O}{ }_{2}\right)=[3.815+(3.815 \times \mathrm{RQ})] \times \dot{\mathrm{VO}}_{2}$

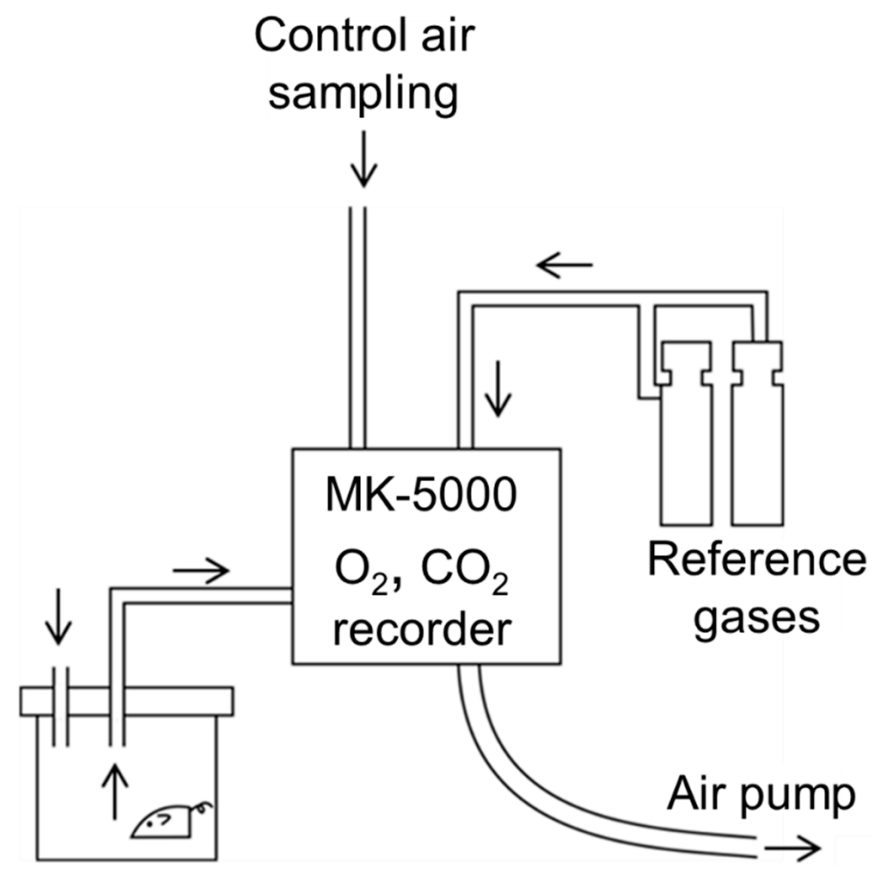

Figure 10. The system of measuring $\mathrm{CO}_{2}$ production and $\mathrm{O}_{2}$ consumption in mice. Inlet air routes from animal chamber, control air, and reference gases are periodically changed. $\mathrm{CO}_{2}$ concentration is measured by infrared absorption analysis. $\mathrm{O}_{2}$ concentration is measured by magneto-electrical analysis (MK-5000) [100].

The measurement of $\dot{\mathrm{VCO}}_{2}$ and $\dot{\mathrm{VO}}_{2}$ is based on the principles of infrared analysis $[15,16]$ and magneto-electrical analysis [102], respectively. The administration of nasal continuous positive airway pressure (CPAP) in patients with sleep apnea has been linked to body weight gain $[103,104]$. Therefore, long-term exposure to intermittent hypoxia may result in greater reductions in $\mathrm{O}_{2}$ consumption and EE. Human and animal studies have examined the metabolic rates. However, the EE or metabolic rates were not found to be decreased in animal models of intermittent hypoxia or in OSAS patients compared to after the treatment with nasal CPAP $[14,100]$. Conversely, Tachikawa et al. reported significant decreases in basal metabolic rate in OSAS patients by nasal CPAP [14]. Non-agitated sleep without airway obstruction enabled by treatment with CPAP may contribute to this phenomenon. Measure of EE and the calculation of RQ by the pulmonary exchange ratio will undoubtedly contribute to obesity research and other research focused on lifestyle-related diseases in the future [100,105-107]. 
When carbohydrates, fat, and protein are oxydized, $\mathrm{RQ}$ are calculated to 1.0, 0.7, and 0.8 , respectively [108]. Recently, Lin et al. monitored both $\mathrm{CO}_{2}$ and $\mathrm{O}_{2}$ concentrations in human breath samples using a home-made gas chromatography/milli-whistle analyzer and reported that the changes in $\mathrm{CO}_{2}$ concentrations (and the index of $\mathrm{CO}_{2} / \mathrm{O}_{2}$ ratio) were related to the changes in blood sugar concentrations [109]. They sugested that their compact gas chromatography system may be used for a non-invasive and time-dependent (continuous and rapid) blood sugar monitoring in the future.

In addition, historically, gas chromatography and mass spectrometry had been often used as the gas analyzer in respiratory research, and the peak expired $\mathrm{PCO}_{2}$ had been measured by this technology [55-57]. The advantage of these methods over the infrared $\mathrm{CO}_{2}$ analysis is that concentrations of multiple gases can be simultaneously measured. Nevertheless, the use of mass spectrometry for respiratory research has decreased since 2000, which is likely because of cost and tehcnical fragility of the mass spectrometers, which require more extensive technical support [57]. Furthermore, the method of photoinduced electron transfer is rapidly developping in various research fields, and $\mathrm{CO}_{2}$ has been reported to be detected using amine-containing fluorophores $[110,111]$. The evaluation of local $\mathrm{CO}_{2}$ concentrations in various small organs of animals might be possible by this technology.

\section{Conclusions}

In summary, measures of $\mathrm{CO}_{2}$ concentrations in the air are done using the infrared analyzer. Data are important for both the climate problem and the regulatory monitoring of buildings to avoid poor aeration and more recently COVID-19 transmission. Measure of arterial $\mathrm{CO}_{2}$ concentration is performed by measuring $\mathrm{PaCO}_{2}$ using the Severinghaus electrode. The most accurate non-invasive alternative method of $\mathrm{PaCO}_{2}$ is $\mathrm{PtcCO}_{2}$. Measure of $\mathrm{CO}_{2}$ production with $\mathrm{O}_{2}$ consumption may be used for further investigation in the various fields of metabolism, obesity with obstructive sleep apnea syndrome, and lifestylerelated diseases.

Author Contributions: Conceptualization, Y.O. and A.U.; formal analysis, A.U.; investigation, I.F., M.I., A.I. and A.M.; writing—original draft preparation, A.U.; writing—review and editing, Y.O., D.G., K.T. and K.M.; supervision, H.T.; project administration, Y.O. and A.U.; funding acquisition, A.U. All authors have read and agreed to the published version of the manuscript.

Funding: This work was partly supported by International University of Health and Welfare.

Institutional Review Board Statement: Not applicable.

Informed Consent Statement: Not applicable.

Data Availability Statement: Not applicable.

Acknowledgments: We thank Airi Umeda for the help of drawing figures.

Conflicts of Interest: The authors declare no conflict of interest.

\section{Abbreviations}

The following abbreviations are used in this manuscript:

$\begin{array}{ll}\text { ABGA } & \text { Arterial blood gas analysis } \\ \mathrm{ACO} & \text { Asthma chronic obstructive pulmonary disease overlap } \\ \mathrm{Ag} / \mathrm{AgCl} & \text { Silver electrode plated with silver chloride } \\ \mathrm{ANOVA} & \text { Analysis of variance } \\ {\left[\mathrm{Cl}^{-}\right]} & \text {Plasma chloride concentration } \\ \mathrm{COPD} & \text { Chronic obstructive pulmonary disease } \\ \mathrm{CO}_{2} & \text { Carbon dioxide } \\ \mathrm{COVID}-19 & \text { Corona virus disease } 2019 \\ \mathrm{CPAP} & \text { Continuous positive airway pressure } \\ \text { E } & \text { Emphysema }\end{array}$




$\begin{array}{ll}\mathrm{EE} & \text { Energy expenditure } \\ \mathrm{H}^{+} & \text {Hydrogen ion } \\ \mathrm{HCO}_{3}{ }^{-} & \text {Bicarbonate ion } \\ {\left[\mathrm{HCO}_{3}{ }^{-}\right]} & \text {Bicarbonate concentration } \\ \mathrm{H}_{2} \mathrm{CO}_{3} & \text { Carbonic acid } \\ \mathrm{ILD} & \text { Interstitional lung disease } \\ {\left[\mathrm{Na}^{+}\right]} & \text {Plasma sodium concentration } \\ \mathrm{NPPV} & \text { Non-invasive positive pressure ventilation } \\ \mathrm{N} . \mathrm{S} & \text { Not significant } \\ \mathrm{OSAS} & \text { Obstructive sleep apnea syndrome } \\ \mathrm{O}_{2} & \text { Oxygen } \\ \mathrm{PaCO} & \text { Arterial partial pressure of carbon dioxide } \\ \mathrm{PaO} & \text { Arterial partial pressure of oxygen } \\ \mathrm{PCO}_{2} & \text { Partial pressure of carbon dioxide } \\ \mathrm{PetCO}_{2} & \text { End-tidal carbon dioxide partial pressure of exhaled gas } \\ \mathrm{PO}_{2} & \text { Partial pressure of oxygen } \\ \mathrm{PtcCO}_{2} & \text { Transcutaneous partial pressure of carbon dioxide } \\ \mathrm{RQ} & \text { Respiratory quotient } \\ \mathrm{SARS}-\mathrm{CoV}-2 & \text { Severe acute respiratory syndrome coronavirus } 2 \\ \mathrm{SAS} & \text { Sleep apnea syndrome } \\ \mathrm{SD} & \text { Standard deviation } \\ \mathrm{SEM} & \text { Standard error of the mean } \\ \mathrm{SpO}_{2} & \text { Percutaneous oxygen saturation } \\ \mathrm{VBGA} & \text { Venous blood gas analysis } \\ \mathrm{VCO}_{2} & \text { Carbon dioxide production } \\ \mathrm{VO}_{2} & \text { Oxygen consumption } \\ \mathrm{V} / \mathrm{Q} & \text { Ventilation/perfusion }\end{array}$

\section{References}

1. Bernstein, A.S. Climate change and infectious disease. In Harrison's Principles of Internal Medicine, 20th ed.; McGraw-Hill Education: New York, NY, USA, 2018; pp. 900-908.

2. The World Data Centre for Greenhouse Gases. World Meteorological Organization. WMO WDCGG Data Summary. WDCGG No. 44. Available online: https://gaw.kishou.go.jp/publications/summary (accessed on 18 August 2021).

3. Eliseeva, O.V. On the determination of maximum permissible carbon dioxide concentrations in the air of apartment buildings and public buildings. Gig Sanit. 1964, 29, 10-15.

4. Goromosov, M.S. The Physiological Basis of Health Standards for Dwellings; Public Health Papers No. 33; World Health Organization: Geneva, Switzerland, 1968. Available online: https:/ /apps.who.int/iris/handle/10665/39749 (accessed on 18 August 2021).

5. Peng, Z.; Jimenez, J.L. Exhaled $\mathrm{CO}_{2}$ as COVID-19 infection risk proxy for different indoor environments and activities. Environ. Sci. Technol. Lett. 2021, 8, 392-397. [CrossRef]

6. Zhu, N.; Zhang, D.; Wang, W.; Li, X.; Yang, B.; Song, J.; Zhao, X.; Huang, B.; Shi, W.; Lu, R.; et al. For the China Novel Coronavirus investigating and research team. A novel coronavirus from patients with Pneumonia in China, 2019. N. Engl. J. Med. 2020, 382, 727-733. [CrossRef]

7. Goyal, P.; Choi, J.J.; Pinheiro, L.C.; Schenck, E.J.; Chen, R.; Jabri, A.; Satlin, M.J.; Campion, T.R., Jr.; Nahid, M.; Ringel, J.B.; et al. Clinical characteristics of COVID-19 in New York City. N. Engl. J. Med. 2020, 382, 2372-2374. [CrossRef]

8. Wiersinga, W.J.; Rhodes, A.; Cheng, A.C.; Peacock, S.J.; Prescott, H.C. Pathophysiology, transmission, diagnosis and treatment of coronavirus disease 2019 (COVID-19): A Review. JAMA 2020, 324, 782-793. [CrossRef]

9. Stoller, J.K.; Hill, N.S. Respiratory monitoring in critical care. In Goldman-Cecil Medicine, 26th ed.; Goldman, L., Schhafer, A.I., Eds.; Elsevier: Philadelphia, PA, USA, 2020; pp. 622-625.

10. Matthay, M.A.; Ware, L.B. Acute respiratory failure. In Goldman-Cecil Medicine, 26th ed.; Goldman, L., Schhafer, A.I., Eds.; Elsevier: Philadelphia, PA, USA, 2020; pp. 625-635.

11. Malley, W.J. Arterial blood gases. In Clinical Blood Gases: Assessment and Intervention, 2nd ed.; Elsevier Saunders: St. Louis, MO, USA; Elsevier: Philadelphia, PA, USA, 2005; pp. 3-34.

12. Bland, J.M.; Altman, D.G. Statistical methods for assessing agreement between two methods of clinical measurement. Lancet 1986, 1, 307-310. [CrossRef]

13. West, J.B. Ventilation/Blood Flow and Gas Exchange, 4th ed.; Blackwell Scientific Publications: Oxford, UK, 1985.

14. Tachikawa, R.; Ikeda, K.; Minami, T.; Matsumoto, T.; Hamada, S.; Murase, K.; Tanizawa, K.; Inouchi, M.; Oga, T.; Akamizu, T.; et al. Changes in energy metabolism after continuous positive airway pressure for obstructive sleep apnea. Am. J. Respir. Crit. Care Med. 2016, 194, 729-738. [CrossRef] [PubMed] 
15. Bate, G.C.; D'Aoust, A.; Canvin, D.T. Calibration of Infra-Red $\mathrm{CO}_{2}$ Gas Analyzers. Plant. Physiol. 1969, 44, 1122-1126. [CrossRef] [PubMed]

16. Ramwell, P.W.; Dawson, J.B. The calibration of infra-red gas analysers for use in the estimation of carbon dioxide. Phys. Med. Biol. 1958, 2, 280-286. [CrossRef]

17. Fowler, R.C. A rapid infra-red gas analyzer. Rev. Sci Instrum. 1949, 20, 175-178. [CrossRef]

18. HORIBA, Ltd. NDIR: Non Dispersive Infrared. Available online: https://www.horiba.com/jp/scientific/core-technology/ndir/ (accessed on 9 May 2021).

19. Permentier, K.; Vercammen, S.; Soetaert, S.; Schellemans, C. Carbon dioxide poisoning: A literature review of an often forgotten cause of intoxication in the emergency department. Int. J. Emerg. Med. 2017, 10, 14. [CrossRef] [PubMed]

20. Duarte, C.M.; Jaremko, Ł.; Jaremko, M. Hypothesis: Potentially systemic impacts of elevated $\mathrm{CO}_{2}$ on the human proteome and health. Front. Public Health. 2020, 8, 543322. [CrossRef]

21. Martin, A.K.T. Shut that window! Open that window! Coronavirus in winter presents new challenge. Japan Times, 28 December 2020.

22. Gilio, A.D.; Palmisani, J.; Pulimeno, M.; Cerino, F.; Cacace, M.; Miani, A.; Gennaroa, G.D. CO 2 concentration monitoring inside educational buildings as a strategic tool to reduce the risk of SARS-CoV-2 airborne transmission. Environ. Res. 2021, 202, 111560. [CrossRef]

23. Morawska, L.; Cao, J. Airborne transmission of SARS-CoV-2: The world should face the reality. Environ. Int. 2020, 139, 105730. [CrossRef] [PubMed]

24. Correia, G.; Rodrigues, L.; Silva, M.G.D.; Gonçalves, T. Airborne route and bad use of ventilation systems as non-negligible factors in SARS-CoV-2 transmission. Med. Hypotheses 2020, 141, 109781. [CrossRef]

25. Office for Novel Coronavirus Disease Control, Cabinet Secretariat, Government of Japan. Suggestion to the Japanese Governmental Officers to Facilitate the Important Writings to Various Guidelines in Order to Prevent COVID-19. 11 November 2020. Available online: https:/ / www.mhlw.go.jp/content/000695178.pdf (accessed on 14 May 2021).

26. Marr, L.; Miller, S.; Prather, K.; Haas, C.; Bahnfleth, W.; Corsi, R.; Tang, J.; Herrmann, H.; Pollitt, K.; Ballester, J.; et al. FAQs on Protecting Yourself from COVID-19 Aerosol Transmission. Version: 1.87. 9 December 2020. Available online: http: / / tinyurl.com/faqs-aerosol (accessed on 31 July 2021).

27. Jiji, K. Four die in fire suppression system accident in Tokyo parking garage. Japan Times, 16 April 2021.

28. Malley, W.J. Blood gas electrodes and quality assurance. In Clinical Blood Gases: Assessment and Intervention, 2nd ed.; Elsevier Saunders: St. Louis, MO, USA; Elsevier: Philadelphia, PA, USA, 2005; pp. 82-113.

29. Severinghaus, J.W.; Astrup, P.B. History of blood gas analysis. III. Carbon dioxide tension. J. Clin. Monit. 1986, 2, 60-73. [CrossRef]

30. McConville, J.F.; Solway, J.; Mokhlesi, B. Disorders of venntilation. In Harrison's Principles of Internal Medicine, 20th ed.; McGrawHill Education: New York, NY, USA, 2018; pp. 2010-2013.

31. Silverman, E.K.; Crapo, J.D.; Make, B.J. Chronic obstructive pulmonary disease. In Harrison's Principles of Internal Medicine, 20th ed.; McGraw-Hill Education: New York, NY, USA, 2018; pp. 1990-1999.

32. DuBose, T.D., Jr. Acidosis and alkalosis. In Harrison's Principles of Internal Medicine, 20th ed.; McGraw-Hill Education: New York, NY, USA, 2018; pp. 315-324.

33. Goldring, R.M.; Kazemi, H. Regulation of ventilation in metabolic acidosis and alkalosis. In Pulmonary Diseases and Disorders, 2nd ed.; Fisherman, A.P., Ed.; McGraw-Hill: New York, NY, USA, 1988; pp. 281-288.

34. Sharma, S.; Hashmi, M.F.; Aggarwal, S. Hyperchloremic Acidosis; StatPearls Publishing: Treasure Island, FL, USA, 2021. Available online: https:/ / pubmed.ncbi.nlm.nih.gov /29493965/ (accessed on 18 August 2021).

35. Malley, W.J. Blood gas classification. In Clinical Blood Gases: Assessment and Intervention, 2nd ed.; Elsevier Saunders: St. Louis, MO, USA; Elsevier: Philadelphia, PA, USA, 2005; pp. 35-57.

36. Malley, W.J. Regulation of acids, bases, and electrolytes. In Clinical Blood Gases: Assessment and Intervention, 2nd ed.; Elsevier Saunders: St. Louis, MO, USA; Elsevier: Philadelphia, PA, USA, 2005; pp. 307-331.

37. American Association for Respiratory Care. AARC clinical practice guideline. Sampling for arterial blood gas analysis. Respir. Care 1992, 37, 913-917.

38. Slutsky, A.S.; Brochard, L. Mechanical ventilation. In Goldman-Cecil Medicine, 26th ed.; Goldman, L., Schhafer, A.I., Eds.; Elsevier: Philadelphia, PA, USA, 2020; pp. 635-641.

39. Severinghaus, J.W.; Honda, Y. History of blood gas analysis. VII. Pulse oximetry. J. Clin. Monit. 1987, 3, 135-138. [CrossRef]

40. Lee, W.W.; Mayberry, K.; Crapo, R.; Jensen, R.L. The accuracy of pulse oximetry in the emergency department. Am. J. Emerg. Med. 2000, 18, 427-431. [CrossRef] [PubMed]

41. Brooks, D.; Wynn, V. Use of venous blood for $\mathrm{pH}$ and carbon-dioxide studies: Especially in respiratory failure and during anaesthesia. Lancet. 1959, 1, 227-230. [CrossRef]

42. Harrison, E.M.; Galloon, S. Venous blood as an alternative to arterial blood for the measurement of carbon dioxide tensions. Br. J. Anaesth. 1965, 37, 13-18. [CrossRef]

43. Brandenburg, M.A.; Dire, D.J. Comparison of arterial and venous blood gas values in the initial emergency department evaluation of patients with diabetic ketoacidosis. Ann. Emerg. Med. 1998, 31, 459-465. [CrossRef]

44. Gokel, Y.; Paydas, S.; Koseoglu, Z.; Alparslan, N.; Seydaoglu, G. Comparison of blood gas and acid-base measurements in arterial and venous blood samples in patients with uremic acidosis and diabetic ketoacidosis in the emergency room. Am. J. Nephrol. 2000, 20, 319-323. [CrossRef] [PubMed] 
45. Kelly, A.M.; Kyle, E.; McAlpine, R. Venous $\mathrm{pCO}_{2}$ and $\mathrm{pH}$ can be used to screen for significant hypercarbia in emergency patients with acute respiratory disease. J. Emerg. Med. 2002, 22, 15-19. [CrossRef]

46. Rang, L.C.F.; Murray, H.E.; Wells, G.A.; MacGougan, C.K. Can peripheral venous blood gases replace arterial blood gases in emergency department patients? Can. J. Emerg. Med. 2002, 4, 7-15. [CrossRef]

47. Harrison, A.M.; Lynch, J.M.; Dean, J.M.; White, M.K. Comparison of simultaneously obtained arterial and capillary blood gases in pediatric intensive care unit patients. Crit. Care Med. 1997, 25, 1904-1908. [CrossRef] [PubMed]

48. McGillivray, D.; Ducharme, F.M.; Charron, Y.; Mattimoe, C.; Treherne, S. Clinical decision making based on venous versus capillary blood gas values in the wellperfused child. Ann. Emerg. Med. 1999, 34, 58-63. [CrossRef]

49. Zavorsky, G.S.; Cao, J.; Mayo, N.E.; Gabbay, R.; Murias, J.M. Arterial versus capillary blood gases: A meta-analysis. Respir. Physiol. Neurobiol. 2007, 155, 268-279. [CrossRef] [PubMed]

50. Umeda, A.; Kawasaki, K.; Abe, T.; Watanabe, M.; Ishizaka, A.; Okada, Y. Hyperventilation and finger exercise increase venousarterial $\mathrm{P}_{\mathrm{CO} 2}$ and $\mathrm{pH}$ differences. Am. J. Emerg. Med. 2008, 26, 975-980. [CrossRef]

51. Umeda, A.; Kawasaki, K.; Abe, T.; Yamane, T.; Okada, Y. Effects of hyperventilation on venous-arterial bicarbonate concentration difference: A possible pitfall in venous blood gas analysis. Int. J. Clin. Med. 2014, 5, 76-80. [CrossRef]

52. Scholander, P.F. Analyzer for accurate estimation of respiratory gases in one-half cubic centimeter samples. J. Biol Chem. 1947, 167, 235-250. [CrossRef]

53. Forbes, A.M.; Behar, M.G.; Smith, T.C. Analysis of oxygen, carbon dioxide and nitrous oxide mixtures with the Scholander apparatus. Anesthesiology 1967, 28, 928-933. [CrossRef]

54. Siobal, M.S. Monitoring Exhaled Carbon Dioxide. Respir. Care 2016, 61, 1397-1416. [CrossRef]

55. Johansson, U.B. Determination of respiratory gases $\left(\mathrm{CO}_{2}, \mathrm{O}_{2}\right.$, Ar and $\left.\mathrm{N}_{2}\right)$ with gas solid chromatography. Scand. J. Clin. Lab. Investig. 1983, 43, 91-94. [CrossRef]

56. Whitesell, R.; Asiddao, C.; Gollman, D.; Jablonski, J. Relationship between arterial and peak expired carbon dioxide pressure during anesthesia and factors influencing the difference. Anesth. Analg. 1981, 60, 508-512. [CrossRef] [PubMed]

57. Arieli, R. Mass spectrometer for respiratory research. Respir. Physiol. Neurobiol. 2010, 170, 183-184. [CrossRef]

58. Malley, W.J. Noninvasive blood gas monitoring. In Clinical Blood Gases: Assessment and Intervention, 2nd ed.; Elsevier Saunders: St. Louis, MO, USA; Elsevier: Philadelphia, PA, USA, 2005; pp. 387-418.

59. Walsh, B.K.; Crotwell, D.N.; Restrepo, R.D. AARC clinical practice guideline: Capnography/Capnometry during mechanical ventilation: 2011. Respir. Care 2011, 56, 503-509. [CrossRef] [PubMed]

60. Falk, J.L.; Rackow, E.C.; Weil, M.H. End-tidal carbon dioxide concentration during cardiopulmonary resuscitation. N. Engl. J. Med. 1988, 318, 607-611. [CrossRef]

61. Panchal, A.R.; Bartos, J.A.; Cabañas, J.G.; Donnino, M.W.; Drennan, I.R.; Hirsch, K.G.; Kudenchuk, P.J.; Kurz, M.C.; Lavonas, E.J.; Morley, P.T.; et al. Adult basic and advanced life support writing group. Part 3: Adult Basic and advanced life support: 2020 American Heart Association guidelines for cardiopulmonary resuscitation and emergency cardiovascular care. Circulation 2020, 142, S366-S468. [CrossRef]

62. Soar, J.; Böttiger, B.W.; Carli, P.; Couper, K.; Deaking, C.D.; Djärv, T.; Carsten, L.; Olasveengen, T.; Paal, P.; Pellis, T.; et al. European Resuscitation Council Guidelines 2021: Adult advanced life support. Resuscitation 2021, 161, 115-151. [CrossRef] [PubMed]

63. American College of Emergency Physicians. Policy Statement: Verification of Endotracheal Tube Placement. Revised January 2016. Available online: https:/ / www.acep.org/patient-care/policy-statements/verification-of-endotracheal-tube-placement/ (accessed on 19 August 2021).

64. Sanders, A.B.; Kern, K.B.; Otto, C.W.; Milander, M.M.; Ewy, G.A. End-Tidal carbon dioxide monitoring during cardiopulmonary resuscitation. A prognostic indicator for survival. JAMA 1989, 262, 1347-1351. [CrossRef]

65. Cheifetz, I.M.; Myers, T.R. Respiratory therapies in the critical care setting. Should every mechanically ventilated patient be monitored with capnography from intubation to extubation? Respir. Care 2007, 52, 423-442.

66. American Society of Anesthesiologists. Standards for Basic Anesthetic Monitoring. Developed By: Committee on Standards and Practice Parameters. Available online: https:/ / www.asahq.org/standards-and-guidelines/standards-for-basic-anestheticmonitoring (accessed on 18 August 2021).

67. Restrepo, R.D.; Nuccio, P.; Spratt, G.; Waugh, J. Current applications of capnography in non-intubated patients. Expert. Rev. Respir. Med. 2014, 8, 629-639. [CrossRef]

68. Duyu, M.; Bektas, A.D.; Karakaya, Z.; Bahar, M.; Gunalp, A.; Caglar, Y.M.; Yersel, M.N.; Bozkurt, O. Comparing the novel microstream and the traditional mainstream method of end-tidal $\mathrm{CO}_{2}$ monitoring with respect to $\mathrm{PaCO}_{2}$ as gold standard in intubated critically ill children. Sci. Rep. 2020, 10, 22042. [CrossRef]

69. Severinghaus, J.W.; Bradley, A.F.; Stafford, M.J. Transcutaneous $\mathrm{PCO}_{2}$ electrode design with internal silver heat path. Birth Defects Orig. Artic. Ser. 1979, 15, 265-270.

70. Severinghaus, J.W.; Stafford, M.; Bradley, A.F. tcPCO $\mathrm{PC}_{2}$ electrode design, calibration and temperature gradient problems. Acta Anaesthesiol. Scand. Suppl. 1978, 68, 118-122. [CrossRef] [PubMed]

71. Huch, R.; Huch, A.; Albani, M.; Gabriel, M.; Schulte, F.J.; Wolf, H.; Rupprath, G.; Emmrich, P.; Stechele, U.; Duc, G.; et al. Transcutaneous PO2 monitoring in routine management of infants and children with cardiorespiratory problems. Pediatrics 1976, 57, 681-690. [PubMed] 
72. Huch, A.; Seiler, D.; Meinzer, K.; Huch, R.; Galster, H.; Lübbers, D.W. Transcutaneous $\mathrm{P}_{\mathrm{CO} 2}$ measurement with a miniaturised electrode. Lancet 1977, 1, 982-983. [CrossRef]

73. Hagiwara, B. Transcutaneous electrodes for blood gas determination. Jpn. J. Med. Electron. Biol. Eng. Iyodenshi Seitai Kogaku 1983, 21, 524-530.

74. Lucey, J.F. Clinical uses of transcutaneous oxygen monitoring. Adv. Pediatr. 1981, 28, 27-56.

75. Wimberley, P.D.; Pedersen, K.G.; Thode, J.; Fogh-Andersen, N.; Sørensen, A.M.; Siggaard-Andersen, O. Transcutaneous and capillary pCO2 and pO2 measurements in healthy adults. Clin. Chem. 1983, 29, 1471-1473. [CrossRef]

76. Rüdiger, M.; Töpfer, K.; Hammer, H.; Schmalisch, G.; Wauer, R.R. A survey of transcutaneous blood gas monitoring among European neonatal intensive care units. BMC Pediatr. 2005, 5, 30. [CrossRef] [PubMed]

77. Delerme, S.; Montout, V.; Goulet, H.; Arhan, A.; Le Saché, F.; Devilliers, C.; Riou, B.; Ray, P. Concordance between transcutaneous and arterial measurements of carbon dioxide in an ED. Am. J. Emerg. Med. 2012, 30, 1872-1876. [CrossRef] [PubMed]

78. Stieglitz, S.; Matthes, S.; Priegnitz, C.; Hagmeyer, L.; Randerath, W. Comparison of transcutaneous and capillary measurement of PCO2 in hypercapnic subjects. Respir. Care 2016, 61, 98-105. [CrossRef]

79. Nishiyama, T.; Nakamura, S.; Yamashita, K. Effects of the electrode temperature of a new monitor, $\mathrm{TCM}_{4}$, on the measurement of transcutaneous oxygen and carbon dioxide tension. J. Anesth. 2006, 20, 331-334. [CrossRef] [PubMed]

80. Restrepo, R.D.; Hirst, K.R.; Wittnebel, L.; Wettstein, R. AARC clinical practice guideline: Transcutaneous monitoring of carbon dioxide and oxygen: 2012. Respir. Care 2012, 57, 1955-1962. [CrossRef]

81. Ruangsetakit, C.; Chinsakchai, K.; Mahawongkajit, P.; Wongwanit, C.; Mutirangura, P. Transcutaneous oxygen tension: A useful predictor of ulcer healing in critical limb ischaemia. J. Wound Care 2010, 19, 202-206. [CrossRef]

82. Umeda, A.; Okada, Y. Comparison of Accuracy: Bland-Altman analysis of alternative examinations in the field of respiratory medicine. Kokyu Junkan Respir. Circ. 2012, 60, 840-848.

83. Aliwalas, L.L.; Noble, L.; Nesbitt, K.; Fallah, S.; Shah, V.; Shah, P.S. Agreement of carbon dioxide levels measured by arterial, transcutaneous and end tidal methods in preterm infants $<$ or $=28$ weeks gestation. J. Perinatol. 2005, 25, 26-29.

84. Tobias, J.D.; Meyer, D.J. Noninvasive monitoring of carbon dioxide during respiratory failure in toddlers and infants: End-tidal versus transcutaneous carbon dioxide. Anesth. Analg. 1997, 85, 55-58.

85. Oshibuchi, M.; Cho, S.; Hara, T.; Tomiyasu, S.; Makita, T.; Sumikawa, K. A comparative evaluation of transcutaneous and end-tidal measurements of $\mathrm{CO}_{2}$ in thoracic anesthesia. Anesth. Analg. 2003, 97, 776-779. [CrossRef]

86. Tingay, D.G.; Stewart, M.J.; Morley, C.J. Monitoring of end tidal carbon dioxide and transcutaneous carbon dioxide during neonatal transport. Arch. Dis. Child. Fetal Neonatal Ed. 2005, 90, F523-F526. [CrossRef] [PubMed]

87. Hirabayashi, M.; Fujiwara, C.; Ohtani, N.; Kagawa, S.; Kamide, M. Transcutaneous PCO2 monitors are more accurate than end-tidal PCO2 monitors. J. Anesth. 2009, 23, 198-202. [CrossRef] [PubMed]

88. Schwarz, S.B.; Wolfram Windisch, W.; Magnet, F.S.; Schmoor, C.; Karagiannidis, C.; Callegari, J.; Huttmann, S.E.; Storre, J.H. Continuous non-invasive $\mathrm{PCO}_{2}$ monitoring in weaning patients: Transcutaneous is advantageous over end-tidal $\mathrm{PCO}_{2}$. Respirology 2017, 22, 1579-1584. [CrossRef]

89. Umeda, A.; Ishizaka, M.; Tasaki, M.; Yamane, T.; Watanabe, T.; Inoue, Y.; Mochizuki, T.; Okada, Y.; Kesler, S. Evaluation of time courses of agreement between minutely obtained transcutaneous blood gas data and the gold standard arterial data from spontaneously breathing Asian adults, and various subgroup analyses. BMC Pulm. Med. 2020, 20, 151. [CrossRef]

90. Kulandavelu, S.; Balkan, W.; Hare, J.M. Regulation of oxygen delivery to the body via hypoxic vasodilation. Proc. Natl. Acad. Sci. USA. 2015, 112, 6254-6255. [CrossRef] [PubMed]

91. Huttmann, S.E.; Windisch, W.; Storre, J.H. Techniques for the measurement and monitoring of carbon dioxide in the blood. Ann. Am. Thorac. Soc. 2014, 11, 645-652. [CrossRef]

92. Janssens, J.P.; Perrin, E.; Bennani, I.; Muralt, B.; Titelion, V.; Picaud, C. Is continuous transcutaneous monitoring of PCO 2 (Tc $P$ $\mathrm{CO}_{2}$ ) over $8 \mathrm{~h}$ reliable in adults? Respir. Med. 2001, 95, 331-335. [CrossRef]

93. Rodriguez, P.; Lellouche, F.; Aboab, J.; Buisson, C.B.; Brochard, L. Transcutaneous arterial carbon dioxide pressure monitoring in critically ill adult patients. Intensive Care Med. 2006, 32, 309-312. [CrossRef]

94. Gerdung, C.A.; Adeleye, A.; Kirk, V.G. Noninvasive monitoring of $\mathrm{CO}_{2}$ during polysomnography: A review of the recent literature. Curr. Opin. Pulm. Med. 2016, 22, 527-534. [CrossRef]

95. Trucco, F.; Pedemonte, M.; Fiorillo, C.; Tan, H.-L.; Carlucci, A.; Brisca, G.; Tacchetti, P.; Bruno, C.; Minetti, C. Detection of early nocturnal hypoventilation in neuromuscular disorders. J. Int. Med. Res. 2018, 46, 1153-1161. [CrossRef]

96. Buekers, J.; Boever, P.D.; Theunis, J.; Houben-Wilke, S.; Vaes, A.W.; Franssen, F.M.E.; Wouters, E.F.M.; Simons, S.; Aerts, J.-M.; Spruit, M.A. Physiological changes differ between responders and nonresponders to pulmonary rehabilitation in COPD. Med. Sci. Sports Exerc. 2021, 53, 1125-1133. [CrossRef]

97. Prieur, G.; Medrinal, C.; Combret, Y.; Lozeron, E.D.; Bonnevie, T.; Gravier, F.E.; Quieffin, J.; Lamia, B.; Borel, J.C.; Reychler, G. Nasal high flow does not improve exercise tolerance in COPD patients recovering from acute exacerbation: A randomized crossover study. Respirology 2019, 24, 1088-1094. [CrossRef] [PubMed]

98. Sasaki, T.; Ishizaka, M.; Kaneko, J.; Umeda, A. Effect of resistance exercise and aerobic exercise on percutaneous oxygen pressure in the lower extremities. Rigakuryoho Kagaku 2020, 35, 855-859. [CrossRef]

99. Mori, M.; Nakagami, H.; Rodriguez-Araujo, G.; Nimura, K.; Kaneda, Y. Essential role for miR-196a in brown adipogenesis of white fat progenitor cells. PLoS Biol. 2012, 10, e1001314. [CrossRef] 
100. Umeda, A.; Miyagawa, K.; Mochida, A.; Takeda, T.; Takeda, K.; Okada, Y.; Gozal, D. Intermittent hypoxia, energy expenditure, and visceral adipocyte recovery. Respir. Physiol. Neurobiol. 2020, 273, 103332. [CrossRef]

101. Shimizu, N.; Maruyama, T.; Yoshikawa, N.; Matsumiya, R.; Ma, Y.; Ito, N.; Tasaka, Y.; Kuribara-Souta, A.; Miyata, K.; Oike, Y.; et al. A muscle-liver-fat signalling axis is essential for central control of adaptive adipose remodeling. Nat. Commun. 2015, 6, 6693. [CrossRef] [PubMed]

102. Pauling, L.; Wood, R.E.; Sturdivant, J.H. An instrument for determining the partial pressure of oxygen in a gas. J. Am. Chem Soc. 1946, 68, 795-798. [CrossRef] [PubMed]

103. Drager, L.F.; Brunoni, A.R.; Jenner, R.; Lorenzi-Filho, G.; Bensenor, I.M.; Lotufo, P.A. Effects of CPAP on body weight in patients with obstructive sleep apnoea: A meta-analysis of randomised trials. Thorax 2015, 70, 258-264. [CrossRef]

104. Chen, B.; Drager, L.F.; Peker, Y.; Vgontzas, A.N.; Phillips, C.L.; Hoyos, C.M.; Salles, G.F.; Guo, M.; Li, Y. Effect of CPAP on Weight and Local Adiposity in Adults with Obstructive Sleep Apnea: A Meta-Analysis. Ann. Am. Thorac. Soc. 2021. [CrossRef]

105. Dedual, M.A.; Wueest, S.; Borsigova, M.; Konrad, D. Intermittent fasting improves metabolic flexibility in short-term high-fat dietfed mice. Am. J. Physiol. Endocrinol. Metab. 2019, 317, E773-E782. [CrossRef] [PubMed]

106. Grandl, G.; Straub, L.; Rudigier, C.; Arnold, M.; Wueest, S.; Konrad, D.; Wolfrum, C. Short-term feeding of a ketogenic diet induces more severe hepatic insulin resistance than an obesogenic high-fat diet. J. Physiol. 2018, 596, 4597-4609. [CrossRef] [PubMed]

107. Umeda, A.; Miyagawa, K.; Mochida, A.; Takeda, H.; Takeda, K.; Okada, Y.; Gozal, D. Effects of normoxic recovery on intima-media thickness of aorta and pulmonary artery following intermittent hypoxia in mice. Front. Physiol. 2020, 11, 583735. [CrossRef]

108. Patel, H.; Kerndt, C.C.; Bhardwaj, A. NCBI Resources: Physiology, Respiratory Quotient. Available online: https://www.ncbi. nlm.nih.gov/books/NBK531494/ (accessed on 4 May 2021).

109. Lin, C.-H.; Wu, L.-X.; Chen, K.-H.; Lo, H.-F.; Lin, K.-C.; Kasai, T.; Chen, C.-C.; Shih, C.-H.; Manzano, M.C.; Santos, G.N.; et al. Non-Invasive and time-dependent blood-sugar monitoring via breath-derived $\mathrm{CO}_{2}$ correlation using gas chromatograph with a Milliwhistle gas analyzer. Anal. Sci. 2020, 36, 739-743. [CrossRef] [PubMed]

110. Sun, W.; Li, M.; Fan, J.; Peng, X. Activity-Based sensing and theranostic probes based on photoinduced electron transfer. Acc. Chem. Res. 2019, 52, 2818-2831. [CrossRef]

111. Herman, P.; Murtaza, Z.; Lakowicz, J.R. Sensing of carbon dioxide by a decrease in photoinduced electron transfer quenching. Anal. Biochem. 1999, 272, 87-93. [CrossRef] 